\title{
Stratigraphic units of the Apulian Tavoliere plain (Southern Italy): Chronology, correlation with marine isotope stages and implications regarding vertical movements
}

\author{
Vincenzo De Santis , Massimo Caldara , Trinidad de Torres , José E. Ortiz \\ Dipartimento di Geologia e Geofisica, Via Orabona 4, Università degli Studi di Bari, 70125 Bari, italy \\ Biomolecular Stratigraphy Laboratory, Madrid School of Mines, C/Rios Rosas 21, E-28003 Madrid, Spain
}

Keywords:

UBSU

Amino-acid racemization

Radiocarbon dating

Marine isotope stage

Pleistocene

\section{A B S T R A C T}

The geologic study of the Apulian Tavoliere plain (Apulia region, southem Italy) is extremely difficult due to the scarcity of outcrops and fauna that could be used for dating.

The survey in progress of the 1:50,000 scale geological sheet no. 409 "Zapponeta" (including the coastal zone of the Apulian Tavoliere) has prompted us to tackle this problem by using a large set of borehole data and the AAR dating method applied to ostracod shells, which are capable of colonizing all types of environment as long as there is water. This alternative approach has allowed us to recognise nine stratigraphic units or synthems and, for the first time in this area, to date them, and to find a correlation between them and the cycles of sea level variation. The recognised stratigraphic units are: the Coppa Nevigata sands (NEA; middle Pleistocene: MIS 17-16), argille subappennine unit (ASP; middle Pleistocene: MIS 15-13), the Coppa Nevigata synthem (NV); middle Pleistocene: MIS 11), the Amendola subsynthem (MLM ; middle Pleistocene: MIS 11), an undifferentiated continental unit (UCI; middle Pleistocene: MIS 8-7), the Foggia synthem (TCF; middlelate Pleistocene: MIS 6), the Carapelle and Cervaro streams synthen (RPL; late Pleistocene: MIS 5-3), and the Inacquata farm synthem (NAQ; Holocene).

Within the RPL unit, a buried Cladocora caespitosa biohem referable to MIS 5.5, lacking in warm fauna, and in which the coral is embedded in clay has been found in some boreholes. This is the first finding of Tymhenian deposits with $C$ c caespitosa along the ltalian Adriatic coast; the presence of this coral in clayey sediments, a very uncommon occurrence, strengthens the hypothesis that the major fossil reefs grew in coastal waters that were characterised by alluvial inputs of fine sediments, higher turbidity, and higher temperature than today. In addition, on the basis of the cument evidence, some consideration about the fauna of the MIS 5.5 layer allows us to hypothesise that the Adriatic Sea underwent a more moderate warming compared to that of the Ionian and Tyrrhenian seas.

Instead, the finding in the NV] unit of a tropical lagoonal deposit with stromatolites referred to MIS 11 proves that the warming in this stage was undoubtedly greater than that of MIS 5.5.

The MM4 borehole, which goes through the MIS 5 layers of the RPL unit, made it possible to recognise two marine phases during MIS 5: the first is referable to the MIS 5.5-5.3 interval, and the second to MIS 5.1. MIS 5.2 is marked by land emersion, whereas no evidence of land emersion between MIS 5.5 and 5.3 has been found.

Also for the first time in this area, uplifting and subsiding areas have been recognised and the vertical movements assessed. In general, the data suggest that the Garganic Apulian foreland and the Amendola highland experienced an uplift, while the central-southern part of the study area, belonging to the Apulian Tavoliere plain, suffered a subsidence with rates increasing from north-northwest to south-southeast. In particular, the finding of the MIS 5.5 buried layer with C. caespitosa has allowed us to fill a gap in the data regarding the recent tectonic movements along the Adriatic coast (Ferranti et al., 2006). This feature proves that there has been a recent subsidence event since MIS 5.5 in the coastal area of the Apulian Tavoliere plain.

\section{Introduction}

The Apulian Tavoliere is the widest plain in Italy, second only to the Po plain. It covers an area of $4300 \mathrm{~km}^{2}$ and is limited to the north by the Gargano Massif, to the west by the Mountains of Daunia, to the 
south by the Murge Highlands, and to the east by the Adriatic Sea. It looks like a monotonous flat expanse, tilted on average of a few degrees towards east-northeast, and almost completely lacking in morphological evidence, except for very low scarps, bordering terraced marine or alluvial deposits, and erosive furrows of mostly seasonal streams that descend from the Apennine chain.

The first geologic setting was obtained with geologic surveys carried out in the $1960 \mathrm{~s}$ and 1970 s, connected with the development of the 1:100,000 scale geological map (Jacobacci et al., 1967; Malatesta et al., 1967; Boni et al., 1969; Merla et al., 1969; Boenzi et al., 1971). New momentum has been given to the studies of the Apulian Tavoliere in the last decade thanks to the realisation of the new 1:50,000 scale geological map (CARG project; Ciaranfi et al., in print; Caldara et al., in print).

The use of the Unconformity-Bounded Stratigraphic Units (UBSU; Salvador, 1987), accepted by the Italian Geological Survey for the new geological map, implies the identification of synthems, which include continental terraced deposits, marine terraced deposits, or both, thus modifying the geological interpretation of the area. However, the problem of the chronological collocation of these terraced units has often been tackled hastily; in fact, their ages have been deduced on the basis of their altitude only, beginning from the end of the lower Pleistocene, which is the hypothesised age for the closing of the Bradanic cycle.

The survey in progress of the $1: 50,000$ scale geological sheet no. 409 "Zapponeta" (including the coastal zone of the Apulian Tavoliere). being carried out by the authors, has prompted us to tackle the problem in a different way, using a large number of boreholes and the amino acid racemization (AAR) dating method applied to ostracod shells.

With these tools, our aim has been to identify the stratigraphic units outcropping in the coastal zone of the Apulian Tavoliere plain, to date them, and to find a correlation between them and the cycles of sea level variation.

\section{Regional setting}

The Apulian Tavoliere belongs to the Bradanic Trough domain (Migliorini, 1937; Malinverno and Ryan, 1986; Royden et al., 1987; Patacca and Scandone, 1989, 2001; Doglioni, 1991). From a structural point of view, the Tavoliere is a part of the "Fossa Bradanica" basin (Bradanic Trough) which formed, beginning in the Lower Pliocene. between the Southern Apenninic chain and the Apulian-Dinaric foreland (Fig. 1). After the basin was filled, some terracing phases linked to both glacio-eustatic oscillations and discontinuous uplift took place.

The geologic history of this area is characterised by the formation, during the Neogene, of a chain-foredeep-foreland system.

The Plio-Pleistocene is characterised by two different geodynamic phases (Ricchetti et al., 1992; Doglioni et al., 1994, 1996).

The first occurred between the middle Pliocene and the lower Pleistocene, when the extreme western sectors of the Apulian foreland underwent strong subsidence (around $2 \mathrm{~mm} / \mathrm{yr}$; Doglioni et al., 1994) because of the subduction under the Apennine chain. During this phase, wide sectors of foreland evolved into a foredeep (Bradanic Trough). In this context, a Bradanic Trough sedimentary cycle (Cantelli, 1960; Ricchetti, 1967, 1981; Azzaroli et al., 1968; Ricchetti et al., 1992) began to accumulate, with marine carbonate deposits of shallow water (calcarenite di Gravina unit) followed by silty-clay hemipelagic deposits (argille subappennine unit).

The second geodynamic phase started in the middle Pleistocene and still continues today: the uplift of the whole Apulian foreland took place (Ricchetti et al., 1992; Doglioni et al., 1994, 1996), testified by the regressive deposits of the Bradanic trough cycle (the upper part of the argille subappennine, sabbie di Monte Marano and congiomerato di Irsina units) and/or by the marine and continental terraced deposits, going from oldest to youngest, according to their progressive elevation from sea level (Ciaranfi et al., 1992).

Glacio-eustatic sea level oscillations occurred together with this ongoing regional polyphase uplift, which complicated the mechanism of regression. As a consequence, according to Caldara and Pennetta (1991, 1993) and Boenzi et al. (1991), each terraced deposit of the Apulian Tavoliere is the result of one or more marine sedimentary cycles and/or continental alluvial phases.

In the new 1:50,000 scale geological map, a regional significance has been attributed to the regressive deposits, with the exception of the upper part of the argille subappennine unit; consequently, they have been grouped in the Apulian Tavoliere supersynthem (Ciaranfi et al., in print), which is primarily constituted by thin alluvial terraced deposits and, subordinately, by marine beach deposits. On the basis of regional considerations, the Apulian Tavoliere supersynthem has been referred to the lower-middle Pleistocene-late Pleistocene (Ciaranfi et al., in print).

In particular, the stratigraphic units of the Apulian Tavoliere supersynthem, sited at the lower heights, and therefore the youngest, are (Ciaranfi et al., in print): the Masseria la Motticella synthem (MLM, which includes the Amendola subsynthem: $\mathrm{MLM}_{1}$ ), the Foggia synthem (TGF), the Carapelle and Cervaro streams synthem (RPL) and the Masseria Finamondo synthem (TPF). These two last units are coeval, but they have been kept separate because they belong to different hydrographic basins.

\section{Methods}

The geologic study of the Apulian Tavoliere is extremely difficult for various reasons: the very low scarps between the terraced units; the homogeneity of the sediments; the outcrop scarcity, the thick superficial soil layer; and the removal or attenuation of the natural morphologies due to the agricultural mechanization.

Despite this, the stratigraphic units were identified thanks to the geological survey correlated with the depth data. We have found and described some natural and artificial sections, of which the following are particularly important (Fig. 1), indicated with the abbreviations: VZ66, near Tomaiolo Farm; VZ68, at the Posta Piana locality; VZ 90, 91, 93, 176, all near Coppa Nevigata Farm; VZ 166, at the Passo Breccioso locality: VZ 169, at the Panetteria del Conte locality; VZ 193, near the Cervaro stream; VZ 214, near the Posta Fossetta locality.

In order to define the thicknesses and depths of the superficial units, data were collected from boreholes (Fig. 2).

The boreholes can be divided as follows:

1) boreholes for geognostic or water research, which made it possible to collect some samples (C1, D3, DF1, IPPO, MM4, MM6, Mn12, and Pt8 boreholes);

2) boreholes for water research that made it possible to recover only the stratigraphies. They have been indicated with the abbreviations " $E$ " and "Ep" followed by an ID number.

Because of the scarcity of suitable fauna for dating, we used two methods extensively, in order to date the stratigraphic units: ${ }^{14} \mathrm{C}$ and AAR, depending on the faunal content of the examined sediments and their ages inferred from their stratigraphic position.

In particular, the AAR method was applied thanks to the common presence of ostracods, which allow the dating of marine, lagoonal and continental sediments, thanks to their ability to colonise all types of environment, as long as there is water.

Amino acids are minor components of mineralized tissues as bone, tooth and shell are. The amino acids are asymmetric and may exist in either a left-handed (L) or a right-handed (D) form, each of which is the mirror image of the other. In all living beings all amino acids are L-amino acids, characterised by the fact that the amino group is at the left side of the molecule. After the death of an organism the L-amino acids diminish while the D-forms accumulate until equilibrium 


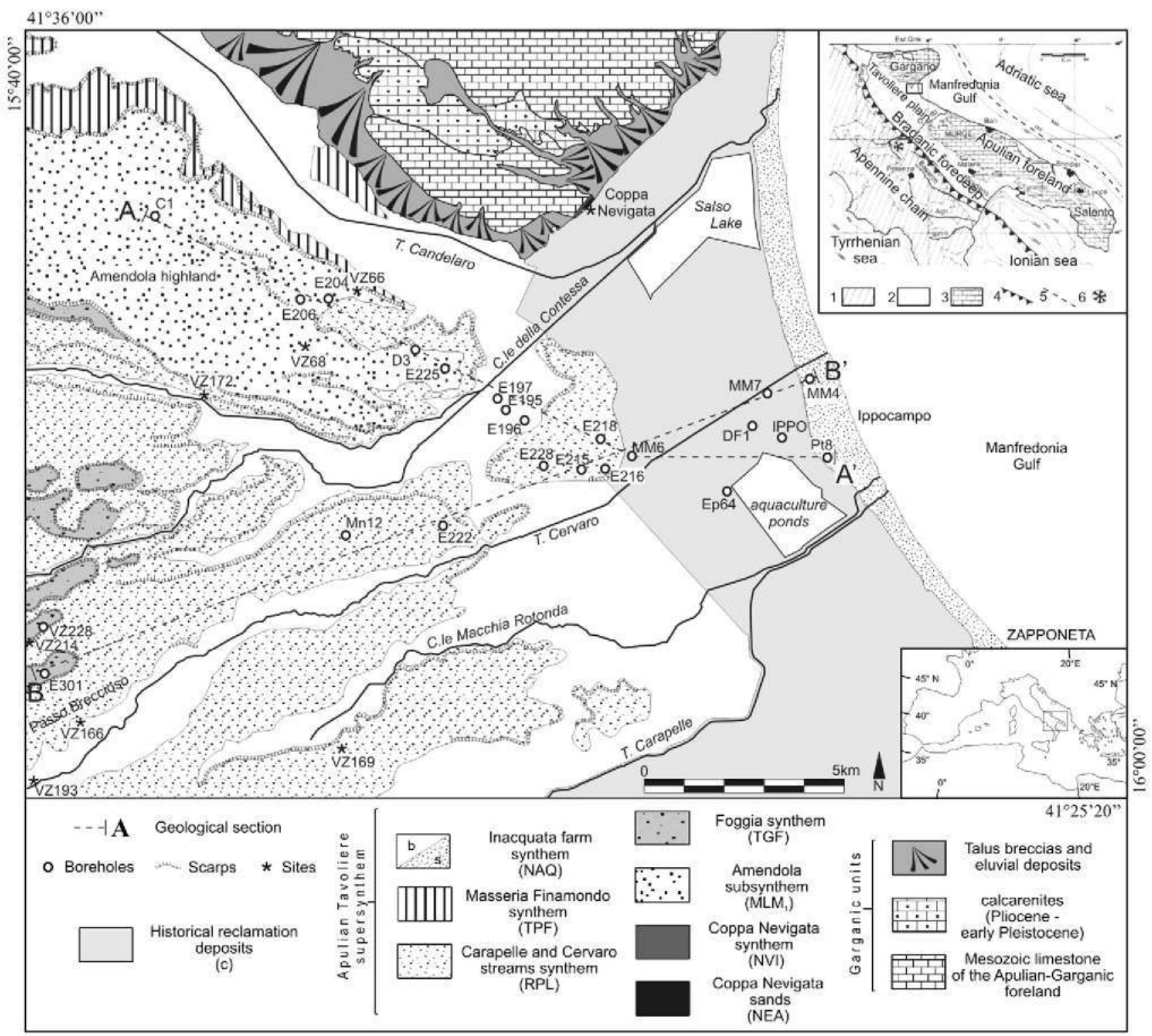

Fig. 1. Schematic geological map of the study area, obtained from an unpublished survey. The Garganic Units and the Masseria Finamondo synthem (TPF) have not been considered in the present study. At the top right the location of the study area in the regional geological context has been reported. $1=$ Mesozoic limestones of the Apulian-Garganic Foreland; $2=$ Apennine chain; 3 = Bradanic foredeep units and terraced units; $4=$ Subduction line of the Apulian-Garganic Foreland under the Apennine chain; $5=$ Last Glacial Maximum shoreline; $6=$ Volcanoes.

conditions are reached. Through time the $\mathrm{D} / \mathrm{L}$ ratio approaches 1 : this process is called amino acid racemization (AAR), a first order kinetics chemical reaction depending on temperature and time (Schroeder and Bada, 1976). The use of racemization values must be done taking into account the thermal history of the sites (McCoy, 1987) and the genera to be sampled. For example, in the Mediterranean area the method covers ca. $1.3 \mathrm{Ma}$ (Ortiz et al., 2002; Clarke and MurrayWallace, 2006) but in the Canary Islands only the last $600 \mathrm{ka}$.

For the present work, many samples have been submitted for dating with the AAR method (Torres et al., 1997; Ortiz et al., 2002, 2004) to the Biomolecular Stratigraphy Laboratory of the Polytechnical University of Madrid.

The method has been applied on ostracod shells of different taxa. The use of ostracods for AAR dating may be very helpful because they can be present in aquatic environments: this allows, at least in theory, sedimentary successions with marine and continental sediments to be dated (like the terraces of the Apulian Tavoliere). For this work, the following ostracods taxa were used: Cyprideis torosa, Candona neglecta, Ilyocypris gibba, Leptocythere sp., Loxoconcha sp., Heterocypris sp., Hemicyprideis sp., Cytheroptheron sp., Carinocythereis sp., Cushmamidea sp., and Heterocythereis sp.

Although monogeneric samples are necessary to reduce taxonomically controlled variability in $\mathrm{D} / \mathrm{L}$ ratios, these three different ostracode genera were employed together to establish the age calculation model. In fact, in previous studies (McCoy, 1988; Oviatt et al., 1999; Kaufman, 2000; Kaufman et al., 2001), only slight differences between $\mathrm{D} / \mathrm{L}$ ratios from different ostracode genera (Candona and Limnocythere) that belong to different phylogenetic ostracode groups (Cypridacea and Cytheracea superfamilies, respectively) have been reported: as much as 0.024 in D-alle/L-Ile values (McCoy, 1988) and 0.022 (Kaufman, 2000) or 0.048 (Kaufman et al., 2001 ) in D/L aspartic acid values. The analyzed ostracodes of this work belong to either of these two superfamilies: Herpetocypris and Ilyocypris to superfamily Cypridacea and Cyprideis to superfamily Cytheracea.

Seven samples have been submitted for dating with the AMS method to the Centre of Dating and Diagnostic (CEDAD) of the University of Lecce (Lab. ID: LTL), to the Centre for Applied Isotopic 


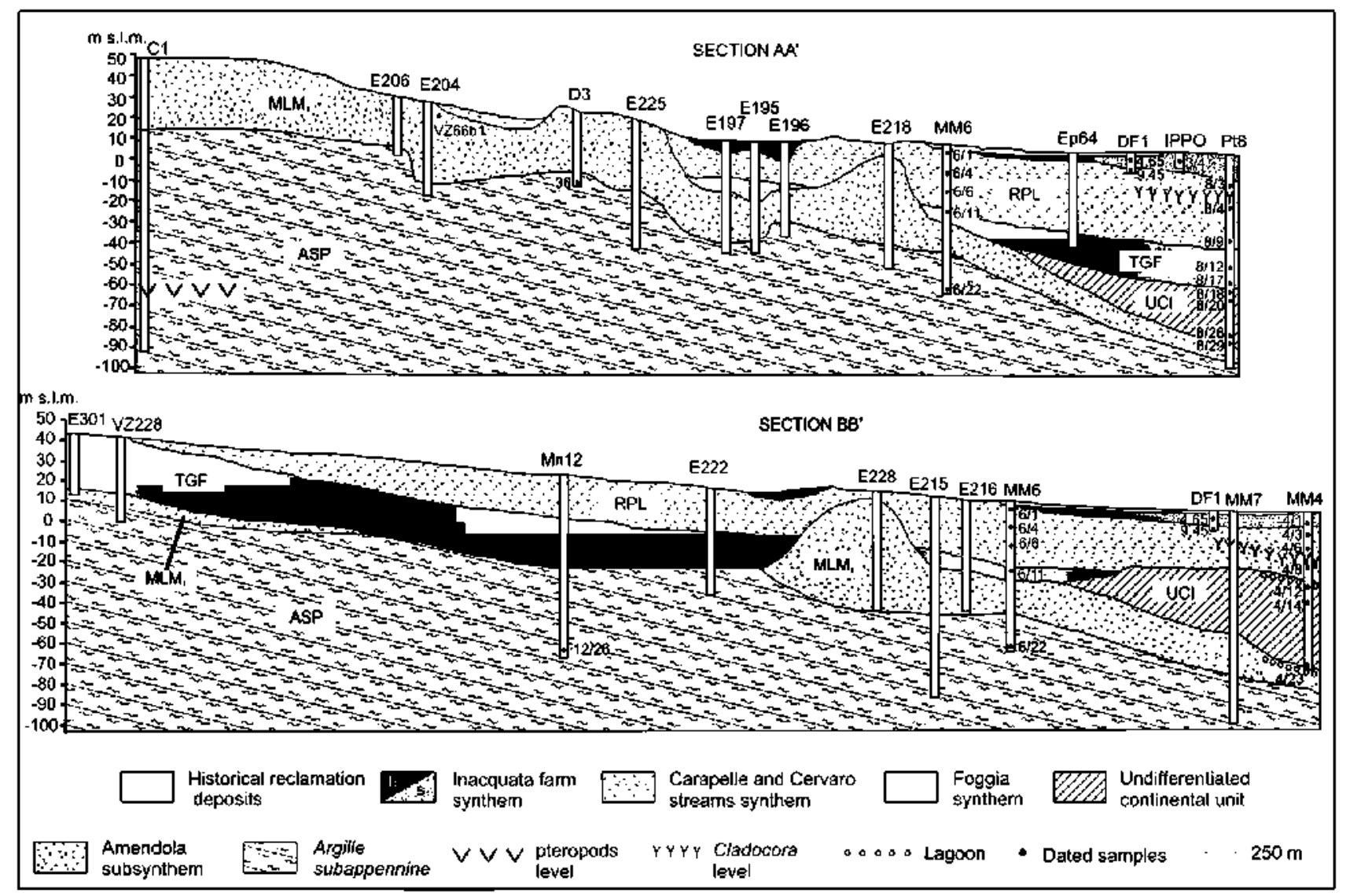

Fig. 2. a) $A A^{\prime}$ geological section; b) $B B^{\prime}$ geological section. The vertical scale has been exaggerated in order to assess the thickness of the units.

Studies of the University of Georgia, USA (Lab. ID: UG) and to the Geochron Laboratories of the Kruger Enterprises Inc., Cambridge Massachusetts, USA (Lab. ID: GX).

Finally, it is considered appropriate to give here a methodological note: all the heights and depths reported in this article are referred to the current sea level.

\section{Results}

\subsection{Stratigraphic units}

The identified stratigraphic units are represented on the reported geological map (Fig. 1) and sections (Fig. 2a, b).

We here report the lithological features and the faunal content of the nine identified units.

\subsubsection{Argille subappennine unit (ASP)}

This unit (Azzaroli et al., 1968), belonging to Bradanic trough cycle, does not crop out in the study area. It was therefore studied using boreholes, specifically C1, D3, MM4, MM6, Mn12, and Pt8.

The lower part, reached only in the $\mathrm{C} 1$ core between the bottom and $-40 \mathrm{~m}$, is made up of grey-blue clays, local marly, with faunas indicative of a deep marine environment (from the epibathyal to the deep circalittoral zones).

In fact, the paleontological content consists of an epibathyal association characterised by Delectopecten abyssorum and Thyasiro sp.; added to these, at around $-62 \mathrm{~m}$, are pteropods such as Limacina inflata, Atlanta cf. peroni, Sryliola subula and Creseis acicula. Upward, the faunal content is characterised by sedimentary instability indicators referable to the circalittoral zone, such as: Corbula gibba, Nuculana pella, Ditrupa arietina and Fustiaria rubescens.
The upper part of the argille subappennine unit, reached in the D3, MM6, Mn 12, and Pt8 cores and in the upper part of the $\mathrm{C} 1$ (above $-40 \mathrm{~m}$ ), shows a regressive trend: it is made up of grey, olive-grey or brown silcy clays, fine sands, and greyish fine sandstones, deposited in circalittoral and infralittoral zones.

In the lowest parts, the presence of Venus multilamella, Turritella ticarinata pliorecens and Amyclina semistriata suggests the circalittoral zone, with a biocoenosis comparable to that of coastal terrigenous muds (VTC sensu Pérès, 1967) characterised by sedimentary instability, as testified by $D$. arietina, N. pelia and $C$ gibba (Di Geronimo, 1984). Upward, the passage into a sandy lithology with Chamalea gallina, Chlamys opercularis, Acanthocardia paucicostata and numerous herbivorous gastropods (e.g., Bittium reticulatum and Tricolia pulla) suggests the infralittoral zone, with a biocoenosis comparable to that of fine well-sorted sand (SFBC sensu Pérès, 1967).

\subsubsection{Coppa Nevigata sands (NEA)}

This unit, never before described, has been found in three artificial outcrops (VZ90, 91 and 93 sites) near the "Coppa Nevigata" farm (Fig. 3). It is transgressive on the Mesozoic limestones, characterised by a surface intensely drilled by Lithodomus. This unit consists of greylight brown, medium- to fine-grained sands with a high microfaunal content, passing upward into silty clays or clayey silts, sterile or with little faunal content; at the base, there is a layer with centimetric pebbles, prevailingly of Garganic origin. The faunal content consists of: C. opercularis, Anomia sp., Mytilaster sp., Limidae sp., Pholadidae sp., Briozoa, Balanus sp., Echinoidea, benthic and planktic foraminifera, and ostracods (C. torosa). In the upper silty-clayey part, only rare ostracods are present.

The NEA unit was deposited in a shallow marine environment (infralittoral zone), with probable passage upward into the continental one. 


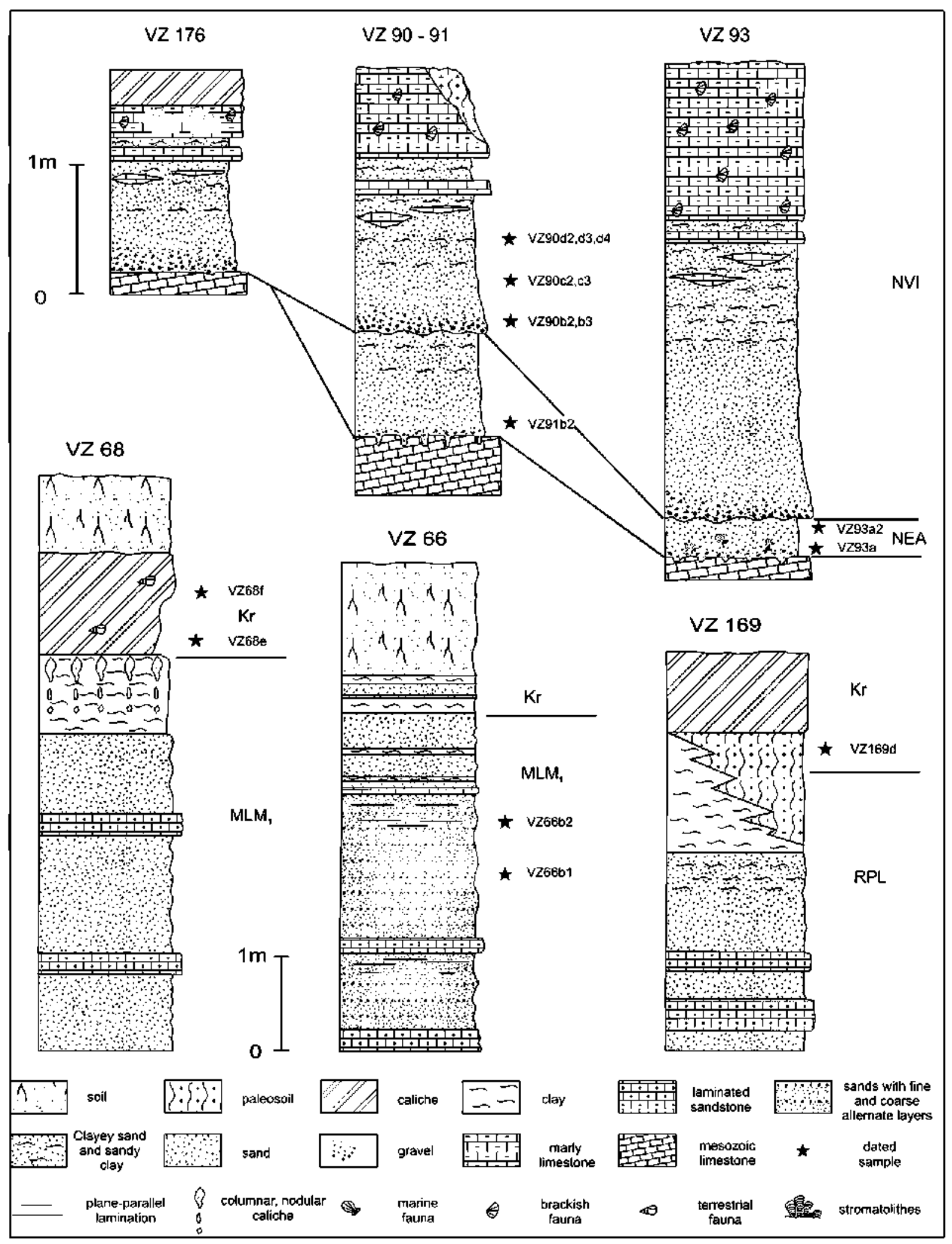

Fig. 3. Stratigraphic sections of the VZ176,90,91 and 93 sites, near Coppa Nevigata locality. Stratigraphic sections of the VZ 68 and VZ 66 sites, where only the MLM 1 unit and caliche (Kr) crop out. Stratigraphic section of the VZ169 site, where the RPL unit and caliche (Kr) clop out.

\subsubsection{Coppa Nevigata synthem (NVI)}

This unit, also described for the first time in this work, has been found in four artificial outcrops (sites VZ90,91, 93 and 176) near the "Coppa Nevigata" farm (Fig. 3). It sometimes unconformably overlies the Mesozoic limestones (VZ 176 site); at other times it occurs with the Coppa Nevigata sands (NEA: VZ 90, 91 and 93 sites). At the base, this unit consists of tawny or yellow ochre sand, with rare polygenic centimetric pebbles. Upward, it passes into light yellow ochre sandy/ clayey silt or clay; some layers are cemented, forming marly limestones or marls that alternate with loose layers: the cemented 
layers contain "nests" of Abra sp. and Cerastoderma glaucum external moulds, as well as centimetric lenses and levels of columnar stromatolites; in the loose levels there is a high ostracod content (C. torosa). The uppermost part of the unit consists of yellow ochre or tawny marly limestones and marls rich in external moulds of Abra sp. and C. glaucum. The basal part of the NVI unit was deposited in a continental environment, with an alluvial plain facies; the upper part was deposited in a lagoon with different confinement zones.

The presence of columnar stromatolites also suggests that this lagoon developed in a tropical climate, and often intertidal environments were present, as currently exists in Shark Bay, Australia (O'Leary et al., 2008).

\subsubsection{Amendola subsynthem $\left(M L M_{1}\right)$}

This unit crops out on the homonymous morphological highland (Amendola highland). It was first reported in the 1:100,000 scale geological map with the name "yellowish sands with coastal fauna" (mark: Qm2; age: Pleistocene; Merla et al., 1969); it has been subsequently described by Ciaranfi (1983) as "Amendola sands". In the new 1:50,000 scale geological map, this unit is described as a marine subsynthem of the Masseria la Motricella synthem (MLM) that belongs to the Apulian Tavoliere supersynthem; its age reported here is middle (?)-late Pleistocene (Ciaranfi et al., in print).

The top of the Amendola subsynthem (MLM $)$ either corresponds to the topographic surface, or is an erosion surface that brings it into contact with overlying TGF or RPL units. The base of the Amendola subsynthem $\left(\mathrm{MLM}_{1}\right)$ does not crop out, but the cores show that this unit unconformably overlies the argille subappennine (ASP), as also testified by the stratigraphic hiatus between the two units, quantified for the first time in this work.

This unit consists of typically tawny-orange or yellow ochre sands, alternating with some levels of fine sand, silt, clay and, at times, coarse sandstone (Fig. 3). The bedding is quasi-horizontal, as shown by the alternating levels of different grain size and by the sandstone layers.

In the few available outcrops (exclusively artificial trenches), the presence of a fine upper part is constant, almost always made up of tawny yellowish to brown clay or clayey silt, rich in white calcareous nodules due to evaporite precipitation. Above this fine part, a layer of calcareous crust, locally called crosta pugliese, occurs.

The faunal content of the Amendola subsynthem consists of: Anomia ephippium, C. operculatis, Chlamys varia, ostrea edulis, Lentidium mediterraneum, Pecten sp. and Donax sp. The faunal content of the upper fine part is composed only of indeterminable fragments of continental gastropods.

From the above data, we deduce that the $\mathrm{MLM}_{1}$ unit was deposited in a very shallow marine environment (upper infralittoral zone); locally, in borehole (e.g. MM4), there are transition facies with a faunal association referable to the eurialine and euritherm lagoon biocoenosis (LEE sensu Pérès, 1967): C. glaucum, Abra, B. reticulatum, and Hydrobiidae sp. The upper fine part, on the other hand, is the result of the alteration of the underlying sands under sub-aerial conditions.

\subsubsection{Undifferentiated continental unit (UCI)}

This unit, also described for the first time in this work, does not crop out and has been found exclusively in boreholes (e.g., MM4 and P(8), where it appears to unconformably overlie the Amendola subsynthem $\left(\mathrm{MLM}_{1}\right)$ and underlie the Carapelle and Cervaro streams synthem (RPL) or Foggia synthem (TGF).

This unit consists of grey-blue, brownish or grey-olive sandy clay, and dark yellow to brown sand; the sandy and clayey levels are often densely alternating. In the Pt 8 core, the whole unit contains white calcareous nodules due to evaporite precipitation. Moreover, the unit contains: 1) in the lower part, a level of bauxite pisolites and coral fragments of Garganic origin; 2) in the central part, some paleosoil layers rich in snail fragments of terrestrial gastropods; 3 ) in the upper part, traces of roots.

The faunal content consists of terrestrial gastropods that are hard to identify due to their fragmented state (Helix sp. and Limax sp.) and fragments of organisms living in freshwater environments, such as: ostracods (C. torosa, Ilyocypris and Hemicyprideis), opercula of freshwater gastropods, and Characeae oogons. In the MM4 borehole, the upper part of this unit passes into a transitional environment of reduced salinity (Fig. 5) characterised by lagoonal fauna such as C. glaucum, Abra segmentum, Hydrobiidae, and ostracods ( $C$. torosa).

The UCI unit was deposited in a continental environment.

\subsubsection{Foggia synthem (TGF)}

On the $1: 100,000$ scale geological map, this unit was not reported as it was included in the "terraced alluvial deposits" (mark: $Q t_{3}$; age: Holocene; Merla et al., 1969). This unit has been introduced in the new 1:50,000 scale geological map, where it has been included in the Apulian Tavoliere supersynthem and attributed to the middle (?)-late Pleistocene (Ciaranfi et al., in print).

In the study area, this unit crops out in some edges (Fig. 1) of the extreme western part and constitutes its higher alluvial terrace. It consists of eterometric, round-to-flat gravels of Apenninic origin. The matrix is made up of grey-brown silty clay or clayey silt; in addition, beds and lenses of grey-light brown sand are present, which at times grade upward into silty clayey components. There are evident concave erosion surfaces in the gravel bodies. Eastwards, the Foggia synthem, found only in boreholes (E195, E196, E197, Ep64, MM6 and Pt8), also contains calcareous gravels of Garganic origin and is characterised by a greater thickness of clayey/silty lenses and beds.

The base of this unit does not crop out, but the boreholes show that it unconformably overlies the argille subappennine unit (ASP), the Amendola subsynthem $\left(\mathrm{MLM}_{1}\right)$, or the undifferentiated continental unit (UCI). The upper boundary corresponds, in outcrop, to the topographic surface; in borehole and in outcrop, the unit appears unconformably overlain by the younger RPL unit.

The faunal content consists of fragments of indeterminable terrestrial gastropods, such as Hygromidae sp. and Helix sp., and bivalves living in freshwater environments, such as Pisidium amnicum, Unio sp, and C. torosa.

The Foggia synthem is the result of deposition in an alluvial plain under a braided pattern.

\subsubsection{Carapelle and Cervaro streams synthem (RPL)}

This unit was not reported on the 1:100,000 scale geological map. but was included in the "terraced alluvial deposits" (mark: Qt ${ }_{3}$; age: Holocene; Merla et al., 1969). In the new 1:50,000 scale geological map, it has been included in the Apulian Tavoliere supersynthem and attributed to the late Pleistocene (work in progress).

This synthem is the widest among those cropping out in the studied area. It is composed of the alluvial deposits of the Carapelle and Cervaro streams, which pass eastwards into shallow water marine deposits found in boreholes only (e.g., MM4 and Pt8). This unit forms the alluvial terrace that is immediately above the recent and present alluvial plain (Inacquata farm synthem); the scarp connecting this unit with the Foggia synthem (TGF) is low and gentle.

The Carapelle and Cervaro streams synthem comprises a wide range of grain sizes: sands, silts, clays, and occasional gravelly layers; the sands can be cemented, forming sandstone layers; the colour of the sediments can change from light brown, to red-yellowish, to brown or light grey. However, the sandy and silty components often exhibit a lamination from parallel to undulating. In the innermost areas, more proximal facies have been found, primarily composed of gravels with sand and silt layers (Passo Breccioso site). The uppermost part of the unit (Fig. 3: VZ169 site) consists of a paleosoil overlain by a level of calcareous evaporite crust, laminated and friable, $50 \mathrm{~cm}$ thick 
at the most; however, there are frequent cases in which one or both of these elements is absent.

The lower boundary consists of an erosion surface on the Foggia synthem (TGF) in outcrop (VZ214 site), and on the Amendola subsynthem $\left(\mathrm{MLM}_{1}\right)$ or the undifferentiated continental unit (UCI) in borehole. The upper boundary corresponds to the topographic surface in outcrop; in borehole, it consists of an unconformity overlain by the younger Inacquata farm synthem (NAQ).

The continental part of the RPL unit is interpreted as an alluvial delta plain deposit, with many overbanks. The faunal content consists of terrestrial gastropods: Cernuella virgata, Helix sp., Cernuella sp. and organisms living in freshwater environments: Bithynia tentaculata, Valvata sp., Flanorbis sp., and ostracods (C. torosa, C. neglecta and Hyocypris sp.).

As already mentioned, toward the east, this unit passes into sediments deposited in a lagoonal or shallow marine environment (infralittoral zone). These sediments are made up of dark grey to greyblue clays, greyish clayey or silty sands, greyish clays and silts, and yellowish sands. They are characterised, from bottom to top, by the presence of (Fig. 5):

i) a Cladocora caespitosa bioherm, dominated by specimens with few, long branches, mixed with a well preserved marine fauna rich in herbivorous and detritivorous gastropods, sessile bivalves and ostracods (C. torosa, Hemicyprideis and Carinocythereis);

ii) fauna indicative of a lagoonal environment (LEE sensu Pérès, 1967): C. glaucum, A. segmentum, Pirenella conica, Ceritium vulgatum and Hydrobiidae;

iii) a clayey paleosoil with carbonate nodules and fragments of terrestrial fauna;

iv) a heterogeneous palaeocommunity (PE sensu Picard, 1965), characterised by sedimentary instability indicators such as C. gibba, Divaricella divaricata, $N$. pella and Tellina distorta, and by species of the infralittoral zone: A paucicostata, Chamelea gallina, Loripes lacteus, Spisula subtruncata, C. torosa, and Cytheropteron.

\subsubsection{Inacquata farm synthem (NAQ)}

On the 1:100,000 scale geological map, two lithological units called "current and recent alluvial deposits" and "current and recent beach and coastal dune deposits" are reported separately. On the new $1: 50,000$ scale geological sheet no. 409 "Zapponeta" (work in progress), we have introduced the Inacquata farm synthem (NAQ). The former two units, therefore, are considered to be subunits of the Inacquata farm synthem.

4.1.8.1. Current and recent alluvial deposits (b). This subunit forms the lower alluvial terrace and the current coastal plain.

It consists of grey clays with sporadic levels of plane-parallel laminated gray silts.

The base of this subunit does not crop out, but, in borehole, it consists of an erosion surface that brings it into contact with the underlying RPL unit and with the Garganic units. The upper boundary corresponds to the topographic surface. The scarp that joins the Carapelle and Cervaro streams synthem (RPL) with subunit b is steeper and easier to locate than the one that joins RPL with the TGF unit.

The faunal assemblage consists of $C$. virgata, Cernuella cisalpina, Hygromiidae and Helix sp.

4.1.8.2. Current and recent beach and coastal dune deposits (s). This subunit crops out along the coastal stretch and consists of fine to coarse marine grey sands. The base of this subunit does not crop out, but, in borehole, it consists of an erosion surface that brings the subunit into contact with the underlying RPL unit. The upper boundary corresponds to the topographic surface.
Subunit b was deposited in a shallow marine environment (infralittoral zone); in particular, the faunal content indicates the fine well-sorted sand biocoenosis (SFBC sensu Pérès, 1967): Mactra stultorum, S. subtuncata, C. gallina and Donax sp. Moving sideways, this biocoenosis passes into the Muddy Sand in Sheltered Areas (SVMC sensu Pérès, 1967) containing: D. divaricata, L. lacteus, T. distorta, Glycimeris glycimeris, Phaxas pellucidus, N. pella, Abra prismatica, and Donax sp. These marine sediments overlie the sandy beaches and/or sandy dune deposits.

\subsubsection{Historical reclamation deposits (c)}

This unit consists of clear to dark grey clays, placed by anthropic works aimed at filling and reclaiming the Tavoliere coastal plain. They extend within the areas that, until the early nineteenth century, were occupied by the Contessa, Versentino and Salso lakes (Caldara et al., 2002).

As previously mentioned, a level of caliche (Caldara et al., in print). called "crosta pugliese" ( $\mathrm{Kr}$ in Fig. 3), locally overlies the MLM, TGF and RPL units, where their upper boundary corresponds to the topographic surface.

The "crosta pugliese" is mainly due to a calcification process that caused an enrichment of carbonate by evaporation under arid or subarid climatic conditions (Carnicelli et al., 1989).

\subsection{Chronological data}

In Tables 1 and 2, we have reported the samples dated respectively with ${ }^{14} \mathrm{C}$ and AAR methods, their ages and their stratigraphic units of origin.

Concerning the AAR datings, some remarks must be made: many ages obtained with the AAR method have been rejected; this has been done in the following cases (7th column of Table 2):

a) for ages obtained from samples that have undergone a recent contamination:

b) for ages with a standard deviation greater or equal to $25 \%$ of the mean value;

c) for ages that differ in an anomalous way from others of the same unit, or are incompatible with the ages of overlying or underlying layers or units, which are considered more reliable thanks to a greater number of valid datings.

Ages from the following samples are considered valid (7th column of Table 2):

h) Sample VZ 172d: although four subsamples were analyzed, three of them were contaminated and only one was used for the age calculation;

k) Sample MM4/1: although falling within case b, its age has a standard deviation that, however, does not cast a doubt on its attribution to the Holocene;

Table 1

AMS datings. For the provenance of the samples see the geological map and sections (Figs. 1-3). Fol the lab. id. see paragraph 3.

\begin{tabular}{lllccl}
\hline Sample & Lab. id. & Material & $\delta^{19} \mathrm{C}(\%)$ & ${ }^{14} \mathrm{C}$ y BP & $\begin{array}{l}\text { Synthem/unit } \\
\text { abbreviations }\end{array}$ \\
\hline VZ193a2 & UG03019 & Hygromiidae & -9.8 & $2100 \pm 30$ & NAQ (b) \\
VZ193b & UG03020 & $\begin{array}{l}\text { Cemuelia virgata, } \\
\text { V }\end{array}$ & -8.7 & $2150 \pm 40$ & \\
V2166b1 & UG03017 & Cermuella virgata & -9.9 & $7150 \pm 40$ & \\
IPPO 3/4 & GX27854 & Posidonia & -26.2 & $2080 \pm 40$ & NAQ (s) \\
DF1-4.65 & UG02378 & Sediment & -24.9 & $5250 \pm 40$ & \\
DF1-9.45 & UG02376 & Sediment & -25.6 & $31,930 \pm 170$ & RPL \\
VZ 169d & UG03018 & Cemuelia virgata & -9.4 & $19,370 \pm 80$ & \\
\hline
\end{tabular}


Table 2

Aspartic acid and glutamic atid D/L ratios of the samples studied in this paper with their corresponding ages: for the provenance of the samples see the geological map and/or sections (Figs. 1-3); for the abbreviations in the 7th and 8th columns see the text.

\begin{tabular}{|c|c|c|c|c|c|c|c|}
\hline $\begin{array}{l}\text { Sample } \\
\text { abbreviations }\end{array}$ & N. subsamples & Material & $D /$ L Asp & D/L Glu & Age (ka) & $\begin{array}{l}\text { Rejected } \\
\text { ages/notes }\end{array}$ & $\begin{array}{l}\text { Synthem/unit } \\
\text { abbreviations }\end{array}$ \\
\hline MM4/1 & 2 & $\begin{array}{l}\text { Cyprideis torosa, } \\
\text { Cushmanidea }\end{array}$ & $0.143 \pm 0.017$ & $0.044 \pm 0.001$ & $4.3 \pm 1.7$ & k & NAQ $(s)$ \\
\hline $\mathrm{Pt} 8 / 3$ & 2 & Hemicyprideis & $0.233 \pm 0.018$ & $0.056 \pm 0.010$ & $28 \pm 10$ & $b, c$ & RPL \\
\hline $\mathrm{Pt} 8 / 4$ & 4 & Cyprideis torosa & $0.365 \pm 0.069$ & $0.113 \pm 0.027$ & $115 \pm 47$ & $b^{*}$ & \\
\hline $\mathrm{Pt} 8 / 9$ & 1 & Gen. indet. & 0.269 & 0.088 & $52 \pm 1$ & a & \\
\hline $\mathrm{V} Z 172 \mathrm{~d}$ & 4 & $\begin{array}{l}\text { Cyprideis torosa, } \\
\text { ilyocypris, Candona } \\
\text { neglecta }\end{array}$ & 0.365 & 0.129 & $127 \pm 8$ & $\mathbf{h}$ & \\
\hline$\sqrt{ } 2172 b 1$ & 5 & Hemicyprideis & $0.310 \pm 0.025$ & $0.200 \pm 0.061$ & $184 \pm 69$ & $b, c$ & \\
\hline$V 2172 a$ & 10 & $\begin{array}{l}\text { Heterocythereis, } \\
\text { Leptocythere, } \\
\text { Henicyprideis }\end{array}$ & $0.267 \pm 0.004$ & $0.149 \pm 0.043$ & $100 \pm 47$ & $b^{+}$ & \\
\hline MM $4 / 3$ & 3 & $\begin{array}{l}\text { Cyprideis torosa, } \\
\text { Cytheropteron }\end{array}$ & $0.291 \pm 0.050$ & $0.098 \pm 0.042$ & $70 \pm 19$ & $\mathrm{~b}^{*}$ & \\
\hline MM4/6 & 4 & $\begin{array}{l}\text { Cyprideis torosa, } \\
\text { Hemicyprideis. } \\
\text { Carinocythereis }\end{array}$ & $0.338 \pm 0.055$ & $0.120 \pm 0.068$ & $98 \pm 17$ & & \\
\hline MM4/8 & 3 & Cyprideis torosa & $0.310 \pm 0.016$ & $0.095 \pm 0.016$ & $75 \pm 22$ & $b^{+}$ & \\
\hline MM6/1 & 2 & Cyprideis torosa & $0.262 \pm 0.011$ & $0.067 \pm 0.010$ & $40 \pm 16$ & $b^{*}$ & \\
\hline MM6/4 & 1 & Cyprideis torosa & 0.263 & - & 50 & & \\
\hline MM6/6 & 6 & Cyprideis torosa & $0.373 \pm 0.024$ & $0.135 \pm 0.025$ & $137 \pm 29$ & $c^{*}$ & \\
\hline MM6/11 & 6 & Cyprideis torosa & $0.385 \pm 0.024$ & $0.273 \pm 0.077$ & $163 \pm 23$ & & TGF \\
\hline $\mathrm{Pt} 8 / 12$ & 3 & Cyprideis torosa & $0.451 \pm 0.009$ & $0.206 \pm 0.022$ & $232 \pm 23$ & $c$ & \\
\hline $\mathrm{Pt} 8 / 17$ & 1 & Cyprideis torosa & 0.408 & 0.119 & $146 \pm 52$ & $b^{+}$ & \\
\hline $\mathrm{Pt} 8 / 18$ & 4 & Cyprideis torosa & $0.417 \pm 0.030$ & $0.193 \pm 0.053$ & $199 \pm 46$ & & UCI \\
\hline $\mathrm{Pt} 8 / 20$ & 1 & Cyprideis torosa & 0.400 & 0.196 & $190 \pm 24$ & & \\
\hline $\mathrm{Pt} 8 / 26$ & 1 & Hlyocypris & 0.484 & 0,197 & $253 \pm 52$ & & \\
\hline $\mathrm{Pt} 8 / 29$ & 3 & Cyprideis torosa & $0.460 \pm 0.020$ & $0.181 \pm 0.0256$ & $248 \pm 12$ & & \\
\hline MM4/12 & 6 & Cyprideis torosa & $0.428 \pm 0.025$ & $0.212 \pm 0.055$ & $220 \pm 53$ & & \\
\hline MM4/14 & 6 & $\begin{array}{l}\text { Cyprideis torosa, } \\
\text { Hemicyprideis }\end{array}$ & $0.484 \pm 0.071$ & $0.253 \pm 0.060$ & $295 \pm 99$ & $b^{*}$ & \\
\hline $\mathrm{MM} 4 / 23$ & 5 & Cyprideis torosa & $0.465 \pm 0.062$ & $0.256 \pm 0.084$ & $283 \pm 99$ & $b^{+}$ & \\
\hline VZ139 & 7 & Cyprideis torosa & $0.422 \pm 0.056$ & $0.272 \pm 0.043$ & $258 \pm 72$ & $\mathrm{~b}$ & MLM $_{1}$ \\
\hline VZ66b2 & 1 & $\begin{array}{l}\text { Cyprideis torosa, } \\
\text { Heterocythereis }\end{array}$ & 0.337 & 0.151 & $127 \pm 22$ & c & \\
\hline VZ66b1 & 7 & Cyprideis torosa & $0.510 \pm 0,039$ & $0.362 \pm 0,042$ & $391 \pm 48$ & & \\
\hline$\sqrt{290 d 4}$ & 6 & Cyprideis torosa & $0.545 \pm 0.034$ & $0.401 \pm 0.037$ & $461 \pm 60$ & & NVI \\
\hline Vzo0d3 & 7 & Cyprideis torosa & $0.515 \pm 0.024$ & $0.380 \pm 0.050$ & $409 \pm 62$ & & \\
\hline$\sqrt{2} 90 \mathrm{~d} 2$ & 7 & Cyprideis torosa & $0.524 \pm 0.015$ & $0.382 \pm 0.037$ & $419 \pm 50$ & & \\
\hline VZ90d1 & 7 & Cyprideis torosa & $0.449 \pm 0.044$ & $0.338 \pm 0.043$ & $322 \pm 78$ & $c$ & \\
\hline$\sqrt{290} 44$ & 7 & Cyprideis torosa & $0.495 \pm 0.021$ & $0.349 \pm 0.049$ & $366 \pm 53$ & $c^{*}$ & \\
\hline$\sqrt{290} c 3$ & 7 & Cyprideis torosa & $0.518 \pm 0.024$ & $0.396 \pm 0.066$ & $421 \pm 74$ & & \\
\hline VZ90<2 & 7 & Cyprideis torosa & $0.527 \pm 0.027$ & $0.398 \pm 0.052$ & $435 \pm 65$ & & \\
\hline VZ90c1 & 7 & Cyprideis torosa & $0.404 \pm 0.024$ & $0.220 \pm 0.051$ & $203 \pm 41$ & c & \\
\hline VZ90b3 & 7 & Cyprideis torosa & $0.539 \pm 0.031$ & $0.388 \pm 0.060$ & $447 \pm 60$ & & \\
\hline VZ90b2 & 7 & Cyprideis torosa & $0.491 \pm 0.029$ & $0.382 \pm 0.081$ & $389 \pm 92$ & $c^{*}$ & \\
\hline $\mathrm{Mn} 12 / 26$ & 1 & $\begin{array}{l}\text { Carinocythereis, } \\
\text { Heterocypris }\end{array}$ & $0.251 \pm 0.015$ & $0.186 \pm 0.011$ & $198 \pm 14$ & a & ASP \\
\hline MM6/22 & 1 & Cytheroptheron & 0.508 & 0.407 & $420 \pm 108$ & $\mathrm{~b}^{*}$ & \\
\hline$D 3 m+36$ & 1 & $\begin{array}{l}\text { Heterocythereis, } \\
\text { Loxoconcha }\end{array}$ & $0.541 \pm 0.035$ & $0.469 \pm 0.087$ & $508 \pm 102$ & & \\
\hline$V_{z} 91 b 2$ & 6 & Cyprideis torosa & $0.641 \pm 0.038$ & $0.458 \pm 0.071$ & $643 \pm 111$ & & NEA \\
\hline$V 293 d 2$ & 14 & Cyprideis torosa & $0.465 \pm 0.067$ & $0.315 \pm 0.086$ & $311 \pm 85$ & c & \\
\hline V293a & 1 & Cyprideis torosa & 0.355 & 0.149 & $135 \pm 12$ & c & \\
\hline
\end{tabular}

For the samples coming from cores, there has been only enough material for one analysis. Therefore, it has not been possible to repeat the dating. Nevertheless, the ages obtained have been used.

A further observation about the use of numerical datings is that only the best ages (those without notes in the 7th column of Table 2 and represented by black vertical lines in Fig. 4) have been taken into consideration. Taking into account all their respective standard deviations, we have defined a hypothetical time range for each unit (Fig. 4). Some mean values of the ages rejected for cases b) and c) are included within the hypothetical time ranges of some units: these ages have been defined as "compatible" (their mean value is represented by white vertical lines in Fig. 4 and they are marked with an asterisk in Table 2).

In any case, the ages are not exhaustive if used alone, so they have been considered with other data such as the lithofacies, the palaeontological content, the sedimentary environment and the general geologic context. All of these elements have contributed to define, for all of the different units, an attributed temporal range (Fig. 4).

\section{Interpretation and discussion}

The collected data made it possible to reconstruct the geologic history of the study area, and to attempt, for the first time, a correlation between the stratigraphic units (Fig. 3) and the cycles of sea level variation.

Regarding the latter, the sea-level curves can represent an important tool for geologists to reconstruct the Quaternary sedimentary cycles and tectonic evolution of uplifted coastal sectors. However. 


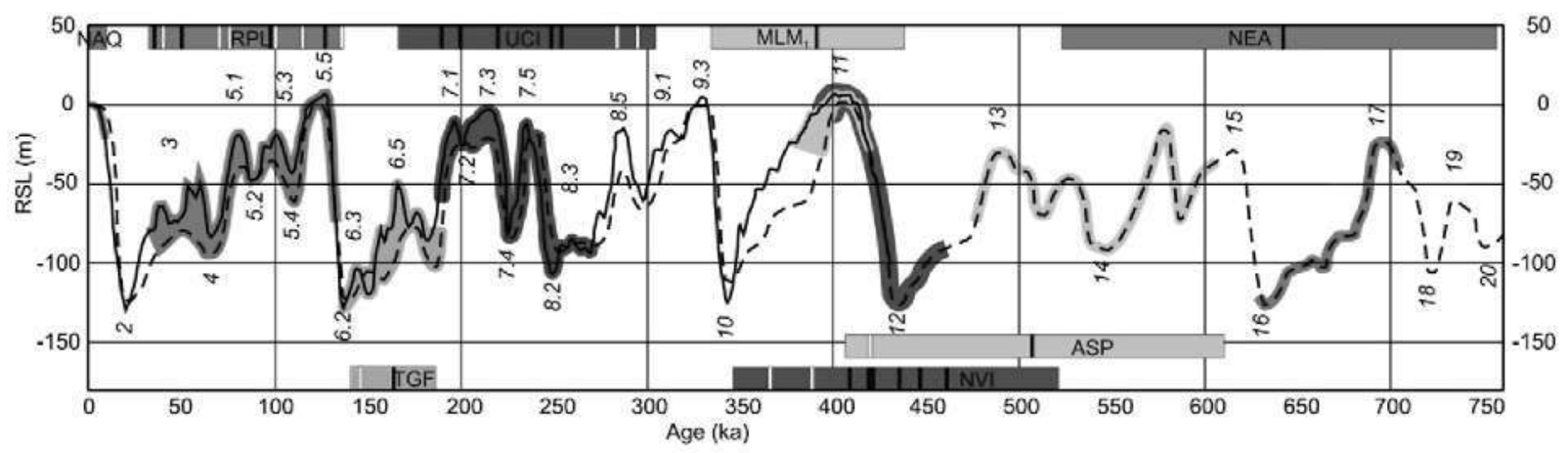

Fig. 4. Relative Sea-Level curve (RSL): Waelbroeck et al., 2002 (continuous line) and Bintanja et al., 2005 (dashed line). The dark vertical lines represent the mean values of the best ages; the gray horizontal belts represent the whole standard deviation of the best ages, which is the hypothetical time range of the units; the white vertical lines represent the mean values of the "compatible" ages. The belts on the sea level curves represent the attributed temporal ranges of the units.

some perplexities arise from their potentially subjective use, exposed as well in Caputo (2007). Nevertheless, for this work, the Waelbroeck et al. (2002) and Bintanja et al. (2005) curves have been followed because they are among the most recent. Moreover, the Bintanja curve covers the whole time range of the identified stratigraphic units. It is still necessary to consider other studies about marine isotope stages, often in disagreement with the two considered curves, that have been taken into account for the reconstruction of the vertical movements (see Section 5.2 - "Vertical movements assessment").

We take into consideration that:

1) many authors indicate some highstands higher than those reconstructed by Bintanja et al. (2005); for MIS 5: Lambeck et al. (2004b); for MIS 7: Chappell and Shackleton (1986), Hearty and Kaufman (2000), Schellmann and Radtke (2004); for MIS 11: Howard (1997), Hearty et al. (1999), Schellmann and Radtke (2004), and Hearty and Kaufman (2000);

2) other authors suggest an exceptionally long MIS 11 (423-360 ka; Zazo, 1999), that allowed the formation of two marine terraces during two different highstands (Schellmann and Radtke, 2004). This assumption is in disagreement with the curve of Bintanja et al. (2005).

\subsection{Reconstruction of the depositional events}

\subsubsection{Middle Pleistocene}

The sedimentary succession of the study area shows a general regressive trend, connected to the Bradanic Trough uplift and its following final emersion. This uplift tendency, according to the literature (Ricchetti et al., 1992; Doglioni et al., 1994, 1996), began during the middle Pleistocene.

The most ancient unit is the Coppa Nevigata sands (NEA): a marine terraced deposit overlying the Mesozoic limestones of the Apulian foreland cropping out at the foot of the Gargano massif. The age obtained for this unit has a very wide standard deviation, so the sedimentation age could range between MIS 20 and MIS 14 . Nevertheless, the vertical succession of facies shows a shift from a shallow marine environment to a continental one, with a transgressive-regressive cycle (Fig. 3 ). This suggests that the unit could be attributed to MIS $17-16$, because this is the only interval with a regressive trend that includes the mean value of the age attributed to NEA unit ( $643 \pm 111 \mathrm{ka} \mathrm{BP;} \mathrm{Fig.} \mathrm{4).}$

The upper part of the argille subappennine unit (ASP) follows. It is made up of circalittoral-infralittoral sediments that probably accumulated in the central part of a wide gulf, open eastwards, that can be considered as the local remains of the Bradanic Trough (Manfredonia paleogulf). The dating shows a very wide standard deviation, so the age of the ASP upper part could vary between MIS 15 and MIS 11, with a mean value around MIS 13 (Fig. 4).
The following unit is the Coppa Nevigata synthem (NVI), which crops out overlying the NEA unit along an erosive contact (Fig. 3). The dating of this unit indicates an age between MIS 13 and MIS 10 . Nevertheless, the vertical succession of facies reveals a transition from a continental alluvial plain at the base to a lagoon with Cerastoderma and Abra in the upper part (Fig. 3). This indicates that the NVI unit accumulated first in a continental environment and later in a sea level rise context. This allows us to restrict the sedimentation age to the MIS 12-11 interval (Fig. 4). In addition, the presence of columnar stromatolites in the upper part of the NVI unit suggests that it is most likely referable to the MIS 11 highstand and it accumulated more or less at sea level at that time. MIS 11 was the longest and warmest interglacial in the last $500 \mathrm{ka}$, in terms of sea surface temperatures, and the finding of MIS 11 stromatolites on the Italian Adriatic side, where warm fauna (Senegalese fauna) has never been found until now, confirms this assumption.

The whole Coppa Nevigata succession (NEA and NVI units) and the age of the argille subappennine upper part, prompts some remarks about the relationship between tectonics, sedimentation and sea level variation cycles.

The NVI unit, whose upper part is referable to the MIS 11 highstand, during which the sea level was higher than at present, unconformably overlies the NEA unit. The latter accumulated in a shallow marine environment during a period (MIS 17-16) characterised by a sea level lower than the present (Imbrie et al., 1984; Bintanja et al., 2005; Fig. 4). It follows that a general uplift of the area occurred between the two depositional phases.

The consequent erosive hiatus between the two units is referable to MIS 15-13. Instead, during this same period, the upper part of the argille subappennine unit (ASP) accumulated in the Manfredonia paleogulf: the standard deviation of its age corresponds very closely with the MIS 15-13 interval (Fig. 4) and, the mean value indicates MIS 13 exactly.

According to the above, it seems that in the period from MIS 15 to MIS 13, there were differences in tectonics and sedimentation between the areas near the Apulian-Garganic foreland (Coppa Nevigata zone, with units NEA and NVI) and the central parts of the Manfredonia paleogulf. In the former, a strong tectonic uplift occurred, with emersion and consequent erosion (erosive hiatus between units NEA and NVI); in the latter, on the other hand, the conditions allowed the deposition of shallow marine sediments (upper part of unit ASP) as these areas, although uplifting, were previously lower than the Apulian-Garganic foreland.

The lack of layers referable to MIS 12 in the argille subappennine unit suggests that, probably only in that period (cold, with a sea level at ca. $-125 \pm 12 \mathrm{~m}$; Bintanja et al., 2005), a generalised emersion occurred, also in the central parts of the Manfredonia paleogulf.

In theory, as well as from the literature (Ciaranfi et al., in print), it is possible that between the lower part (clayey and of the bathyal 
zone) and the upper one (coarser and of the circalittoral-infralittoral zone) of the argille subappennine unit, there is an erosion surface, but there is not sufficient evidence for this hypothesis. The following unit is the Amendola subsynthem $\left(\mathrm{MLM}_{1}\right)$; the age obtained for its middle-upper part suggests that it accumulated during the MIS 11 sea level rise and/or highstand (Fig. 4), which reactivated the Manfredonia paleogulf as a marine sedimentary basin, allowing the deposition of this unit.

Therefore, the NVI and MLM units would be, at least partly, coeval. However, the separation between the outcropping areas of the two units (Fig. 4), the different sedimentary environments, and the different lithologies have suggested keeping them separate. This choice has also been adopted as a consequence of some studies on MIS 11, indicating that it was exceptionally long (423-360 ka), and allowed the formation of two marine terraces during two different highstands (Zazo, 1999; Schellmann and Radtke, 2004).

The coevality of these two units suggests that the MIS 11 transgression caused the sedimentation of infralittoral sands $\left(M M_{1}\right.$ unit) in the central parts of the Manfredonia paleogulf, while in the areas near the Gargano highland, it created conditions favourable to the development first of an alluvial environment and later of a lagoonal one (NVI unit).

Currently, it is not possible to establish when the sedimentation of the $M L M_{1}$ unit ended: there are no traces in the study area of the following sea level oscillations, which occurred from MIS 10 to MIS 8.5 .

In any case, an important erosion phase should have occurred during the MIS 8.4-8.2 interval, when the sea level fell to ca. $-110 \mathrm{~m}$ (Waelbroeck et al., 2002) or ca. $-90 \mathrm{~m}$ (Bintanja et al., 2005), exposing wide areas to subaerial erosion.

During the MIS 8.4-8.2 interval, but even more during the following sea level rise due to the onset of MIS 7, in the eastern part of the study area, favourable conditions for alluvial sedimentation were created; as a consequence, continental aggradational and progradational bodies were deposited, forming the undifferentiated continental unit (UCI). During the MIS 8.4-MIS 7 interval, continental sedimentation occurred because the sea level remained below what it is today (Waelbroeck et al., 2002; Bintanja et al., 2005). Only in the most eastern areas does the UCl unit record a partial marine ingression during substage 7.3 , represented by a lagoonal facies (MM4 borehole; Fig. 5). At the same time as the deposition of UCI, the erosive phase, contemporary to the tectonic uplift, continued in the immediate hinterland, remodelling the topographic surface.

After the UCl unit was deposited, only the eastern part of the study area was involved in moderate subsidence (see Section 5.2 - "Vertical movements assessment"), which brought the UCI unit to its present position (Fig. 2).

During the following MIS 6 , the sea level fell to ca. $-125 / 130 \mathrm{~m}$ (Waelbroeck et al., 2002; Bintanja et al., 2005), and the coastline positioned itself many kilometres off the present coastline. In this situation, the erosion phase of the inland areas reached its maximum with the vertical incision of the land surface shaped during MIS 8 and 7 . In these fluvial valleys, the Foggia synthem (TGF) accumulated; it is characterised by braided plain sediments, due to many subparallel rivers that deposited thin gravelly bodies. This process is similar to those reported for other rivers on the Italian Adriatic coast (Coltorti and Farabollini, 2008).

From the literature, braided pattern occurs in rivers with high valley gradient and/or a large sediment loads (Schumm and Kahn, 1972). During a glacial period with a sea level lowstand, the valley gradient increases; moreover, the cool climate causes an increase in the discharge variability, bed load size and substratum erodibility (Leigh et al., 2004). As a consequence, the probability of braiding increases during a glacial period with sea level lowstand. The Foggia synthem deposits, filling the valleys, isolated the highlands such as that of Amendola which, unlike in the eastern areas, was characterised

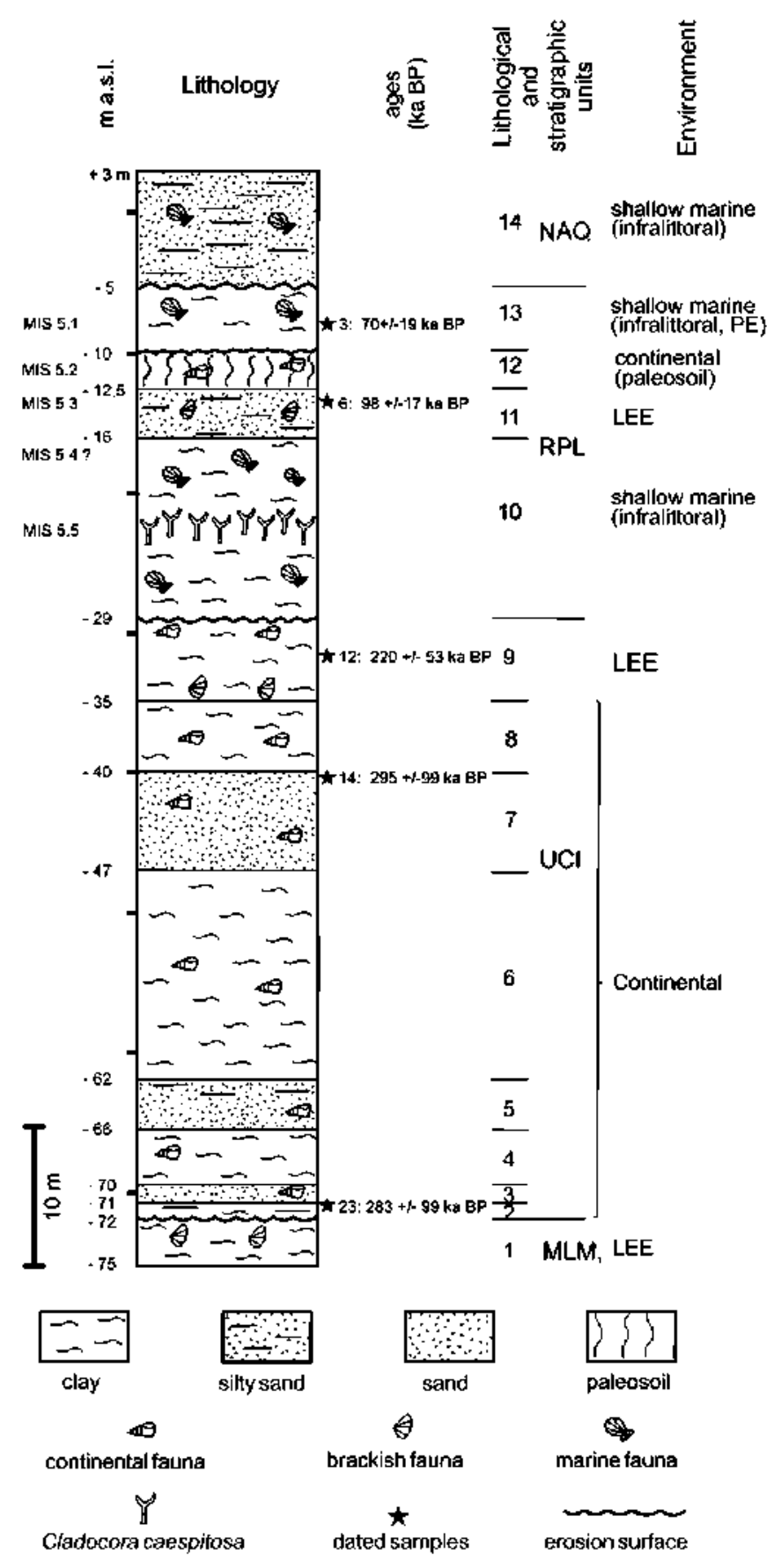

Fig. 5. Stratigraphy of the MM4 borehole, with the recognised lithological units, the locations and the ages of samples dated with the AAR method.

by a continuous uplift until this period (see Section 5.2, "Vertical movements assessment").

\subsubsection{Late Pleistocene. Focusing on MIS 5.5}

The Carapelle and Cervaro streams synthem (RPL) accumulated during MIS 5-3 interval (Fig. 4), with a preponderant contribution during MIS 5.

The presence of a layer with C. caespitosa, found in boreholes at about $-22 \mathrm{~m}$ (Fig. 5), is the most important characteristic of the RPL unit.

Fig. 5 shows the stratigraphy of the MM4 borehole, with the recognised lithological units, their depositional environments, and the locations and ages of samples dated with the AAR method.

In particular, the age of sample MM4/6 ( $98 \pm 17 \mathrm{ka} B P$ ) and its location, about $9 \mathrm{~m}$ above the $C$. caespitosa layer, allows us to attribute 
the latter to MIS 5.5, in analogy to other MIS 5.5 deposits in the Apulia region, rich in C caespitosa (Belluomini et al., 2002).

At a few sites around the Mediterranean, the Tyrrhenian sediments contain $C$ coespitosa, whose uranium series radiometric ages cluster around isotopic stages 7.1 and 5.5 (Sivan et al., 1999).

Even more rare are the MIS 5.5 buried layers with $C$ caespitosa, generally found in alluvial plain areas. In Italy, the layer of the Versilia plain can be found at a depth between -68 and $-71 \mathrm{~m}$ (Antonioli et al., 1999; Nisi et al., 2003), and that of the Volturno plain at a depth of $-50 \mathrm{~m}$ (Romano et al., 1994). Other buried layers referable to MIS 5.5 have been found only in the south-eastern Po plain, at a depth between -85 and $-117 \mathrm{~m}$ (Amorosi et al., 1999a,b, 2004), and in the Sarno plain, at a depth of $-29 \mathrm{~m}$ (Barra et al., 1991). In the latter cases, however, the Tyrrhenian layers are lacking in warm fauna and C. caespitosa.

The $C$. caespitosa found in the Apulian Tavoliere buried layer is embedded in clay: the depositional environment was shallow marine (infralittoral zone), close to an alluvial coastal plain, where terrigenous inputs were discharged by the streams that flow into the Adriatic Sea.

In both buried and outcropping MIS 5.5 deposits with $C$. caespitosa, in Italy and around the Mediterranean (Table 3), the association of this coral with clayey sediments is certainly less common than the association with sand or coarse sediments, often carbonatic. Even today, colonies of $C$. crespitosa occur on rocky or sandy bottoms (Kruzic et al., 2008).

One of the few examples of MIS 5.5 layers with $C$. caespitosa embedded in predominantly clayey sediments where marls crop out is in the "il Fronte" section, near Taranto (Apulia, southern Italy; Dai Pra and Hearty, 1988). Nevertheless, it is possible that the scarcity of MIS 5.5 deposits with C. caespitosa embedded in clay is due only to the fact that this kind of sediment characterised marine environments close to coastal alluvial plains, which, since MIS 5.5, have generally undergone subsidence; thus, the MIS 5.5 layers are buried under more recent deposits and exposures are not available.

The Tavoliere MIS 5.5 layer with $C$. caespitosa strengthens the hypothesis that the major fossil reefs grew in coastal waters characterised by alluvial inputs of fine sediments, higher turbidity and higher temperatures than today (Peirano et al., 1994, 1998).

Finally, another characteristic of the Tavoliere MIS 5.5 layer is the total lack of warm fauna.

Up to now, along the Adriatic coast, MIS 5.5 deposits containing $C$ coespitosa and/or warm fauna have never been found; in general, remnants of the MIS 5.5 marine terraces along the Adriatic coast are limited and poorly constrained regarding timing and elevation. An indirect age constraint is available on the central Apulian coast near
Torre Santa Sabina (Marsico et al., 2003), where a coastal deposit situated at about $+3 \mathrm{~m}$ overlies a colluvial deposit bearing late Paleolithic Mousterian flint and thus could be of MIS 5.5 age.

Another level referable to MIS 5.5 along the Adriatic coast is the already mentioned buried level in the south-eastern Po plain. In this case, the attribution of the deposit to MIS 5.5 is based on pollen series correlation (Amorosi et al., 1999a,b, 2004).

The finding of the Tavoliere MIS 5.5 layer with C caespitosa, but lacking in warm fauna, indicates that the MIS 5.5 warming encouraged the spreading of this coral in the southern Adriatic, but was not strong enough to allow the entry of warm fauna in this sea.

The non-spreading of warm fauna along the Italian Adriatic coast could be due only to the counter-clockwise circulation of sea currents that characterise the Adriatic Sea. However, until now, the lack of evidence for warm fauna along the Adriatic coasts of Albania and Croatia confirms the hypothesis that the Adriatic Sea underwent a more moderate warming than the lonian and Tyrrhenian seas, during MIS 5.5.

Thus, different paleoceanographic conditions occurred between the Adriatic and the Tyrrhenian and Jonian seas, involving sea surface temperature (SST), deep cool water production and upwelling.

In comparison, the MIS 11 warming was undoubtedly greater than MIS 5.5 one. In fact, as already mentioned, it allowed the development, along the Adriatic Sea, of a tropical lagoon with stromatolites (Coppa Nevigata synthem).

A recent alternative hypothesis that may explain the lack of warm fauna in the fossil banks of $C$. caespitosa is that they may have developed under conditions comparable to those recorded today along the Croatian coast, where cold winds or inputs of freshwater lower the SST (Peirano et al., 2009). Thus, during MIS 5.5, the Manfredonia Gulf SST could be lower than that of the open Adriatic Sea, if there were local mitigating factors. Nevertheless, so far, there is no evidence for this hypothesis.

Data about relative sea level oscillations during the whole MIS 5 can be inferred from MM4 borehole (Fig. 5), thanks to the improved quality of the core and the existence of two dates; among these, the $98 \pm 17$ ka age is good and allows us to refer lithological unit 11 to MIS 5.3; the $70 \pm 19$ ka date has a large standard deviation that places lithological unit 13 within the 89-51 ka BP range. However, taking into account the fact that unit 13 was deposited in a shallow marine environment and is transgressive on the underlying paleosoil, it can be reasonably referred to MIS 5.1 .

From these elements, we can infer that the sedimentation was continuous from MIS 5.5 ( $C$. caespitosa layer) to MIS 5.3, with a regressive trend testified by the transition from shallow marine to lagoonal deposits (Fig. 5): no evidence for land emersion between these substages has been found in the area. During MIS 5.2, there was

Table 3

Localities where MIS 5.5 deposits with Cladocora caespitosa are present, in Italy and around the Mediterranean; for each locality are reported also the sediments in which the C. caespitosa is embedded.

\begin{tabular}{|c|c|c|c|c|c|}
\hline Country & Region & Locality & Associated sediment & References & Notes \\
\hline \multirow[t]{11}{*}{ Italy } & Tuscany & Versilia plain & Marine transgressive sands & Antonioli et al. (1999), Nisi et al. (2003) & Buried \\
\hline & Campania & Cilento & Biocalcarenites & Esposito et al. (2003) & \\
\hline & & Sorrentine peninsula & Biogenic limestones with mollusc shells & Brancactio et al. (1978) & \\
\hline & & Volturno plain & Marine sand & Romano et al. (1994) & Buried \\
\hline & Apulia & Taranto area & Calcarenites, biocalcarenites, "panchine" and sands & Belluomini et al. (2002) & \\
\hline & & Torre Castiglione & Calcarenites & Dai Pla and Hearty (1988) & \\
\hline & & Castellaneta Marina & Polygenic conglomerates in a sandy matrix & Caldara (1986) & \\
\hline & Calabria & Crotone peninsula & Biostromal limestones or calcarenites & Gliozzi (1987), Zecchin et al. (2004) & \\
\hline & & Vibo Valentia Marina & Fossiliferous coarse quartz sands & Balescu et al. (1997). Dai Pra et al. (1993) & \\
\hline & Sardinia & Sa Illetta island & Littoral sands & Ulzega and Hearty (1986), Hearty (1986) & \\
\hline & & Calamosca & Beach conglomerates with a sandy matrix & Ulzega and Hearty (1986), Hearty (1986) & \\
\hline \multirow[t]{2}{*}{ Spain } & Mallorca & Son Grauet & Calcarenites & Hearty (1987) & \\
\hline & Alicante & Cabo de Huertas & $\begin{array}{l}\text { Carbonate cemented bioclastic sands and } \\
\text { gravels or bioclastic sandstones and gravels }\end{array}$ & Tortes et al. (2000) & \\
\hline Tunisia & Monastyr & Molnastyl & Calcarenites, sands and beach conglomerates & Miller and Paskoff (1986) & \\
\hline Cyprus & Southem cypius & Many localities & Calcarenites & Poole et al. (1990) & \\
\hline
\end{tabular}


an emersion with the consequent formation of a paleosoil (represented by lithological unit 12), truncated by an erosional surface. Later, during MIS 5.1, a new transgressive phase allowed the deposition of the lithological unit 13.

This pattern, with two depositional phases, the first referable to MIS 5.5-5.3 and the second to MIS 5.1, is in agreement with that reported by Belluomini et al. (2002) for the MIS 5 deposits of the Taranto area.

\subsubsection{Holocene}

The MIS 2 onset puts an end to the RPL sedimentation: the sea level fell to ca. $-125 \pm 5 \mathrm{~m}$ (Fleming et al., 1998; Waelbroeck et al., 2002); the base level lowering caused a new phase of vertical incision. Still, during MIS 2, the alluvial plain surface was affected by pedogenesis phenomena, with the formation of a paleosoil that very often closes lies at the top of the RPL unit; in fact, the age of the sample from this paleosoil (VZ 169d; Table 1) is referable to the Last Glacial Maximum (LGM).

The following Holocene NAQ unit is represented by the current and recent beach and coastal dune deposits ( $s$ ) and the current and recent alluvial deposits (b): these are referable to the transgression phase between the MIS 2 lowstand and the current sea level (Caldara and Simone, 2005).

\subsection{Vertical movement assessment}

In this paragraph, we report some remarks about the tectonic vertical movements, calculated for the first time in the study area.

It is extremely difficult to calculate the vertical movements. In doing so it would require: I) that there be some sea level markers; II) that they be correctly dated; III) that the corresponding sea level be known; [V) that their sedimentation depth be estimated with an accurate approximation. Since all of these evaluations have a certain degree of approximation that increases with time, we can only try. according to recent studies, to estimate the vertical movements.

Some first considerations concern the coastal zone of the study area, which is affected by a clear subsidence. In particular, it is possible to provide an indication of the subsidence thanks to the Pt8 and MM4 boreholes. In both, the RPL unit is characterised by the presence of a C. caespitosa bioherm at a depth of ca $-22 \mathrm{~m}$. The faunal assemblage of the bioherm allows us to hypothesise that the sea bottom was at a depth of roughly $2 \mathrm{~m}$ (however no more than $5 \mathrm{~m}$ ). As the bioherm has been referred to MIS 5.5, and in that period the sea level was at $+6 \pm 3 \mathrm{~m}$ (Lambeck et al., 2004b), the calculated subsidence, from MIS 5.5 to the present day, is about $-26 \pm 3 \mathrm{~m}$, with a rate between -0.23 and $-0.18 \mathrm{~mm} / \mathrm{yr}$ and a mean value of $-0.21 \mathrm{~mm} / \mathrm{yr}$ (Fig. 7).

The finding in the Apulian Tavoliere of MIS 5.5 can be added to the few reports of the same stage along the Adriatic coast (Ferranti et al., 2006). In particular, this datum represents the greatest subsidence rate calculated for the southern and central Adriatic coast. Until now, the maximum subsidence rate $(-0.02 \mathrm{~mm} / \mathrm{yr})$ has been calculated at the Torre Santa Sabina site (Marsico et al., 2003). The subsidence rate calculated from MIS 5.5 to the present for the Apulian Tavoliere plain is comparable to those of the Trieste, Versilia and Sarno plains (respectively $-0.21,-0.28$ and $-0.26 \mathrm{~mm} / \mathrm{yr}$ ), while it is quite distinct from those of the greatest Italian plain (Po plain), which are between -0.80 and $-1 \mathrm{~mm} / \mathrm{yr}$ (Ferranti et al., 2006). This first report of subsidence affecting the Apulian Tavoliere areas from MIS 5.5 to the present proves that the Apulian Tavoliere Plain also behaves, from a tectonic point of view, like other Italian coastal plains; this allows us to modify the regional frame reported in Ferranti et al. (2006). showing a slow to rapid uplift moving northward along the Adriatic coast (Fig. 6).

In the MM4 borehole, the upper part of the UCI unit, sited at $-32 \mathrm{~m}$ (i.e., $10 \mathrm{~m}$ below the $C$. caespitosa level), is represented by a Iagoonal deposit dated at $220 \pm 53 \mathrm{ka}$, therefore referable to substage

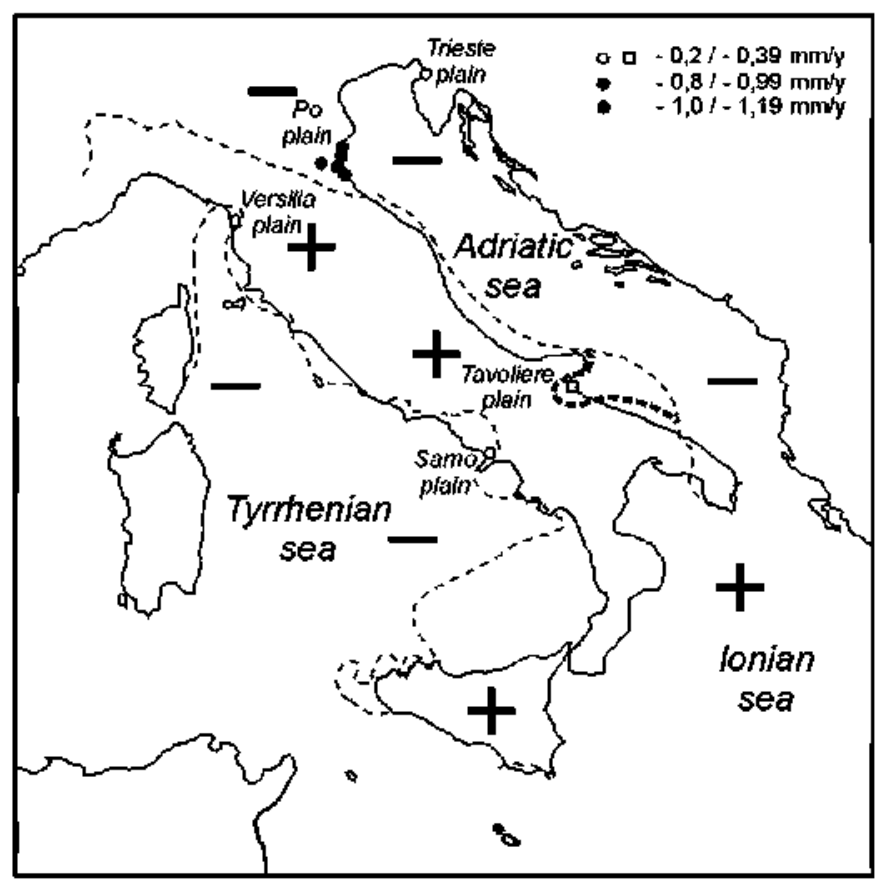

Fig. 6. Simplified sketch of the vertical tectonic behaviour in Italy deduced from the elevation of the MIS 5.5 markers (modified from Ferranti et al., 2006). The dashed thin line is the limit between subsiding and uplifting areas. The circles indicate the subsidence rates of some Italian codstal plains. The square indicates the subsidence of the Apulian Tavoliere plain (mean value: $-21 \mathrm{~mm} / \mathrm{yr}$ ). The dashed thick line is the modification, for the Apulian Tavoliere plain, of the line that separates subsiding and uplifting areas.

7.3 (Fig. 5). In this work, a MIS 7.3 highstand at $-10 \mathrm{~m}$ has been carefully considered, as this is an intermediate value among those reported in Schellmann and Radtke (2004), Bintanja et al. (2005) and Waelbroeck et al. (2002). In addition, according to Lambeck et al. (2004a) and Ferranti et al. (2006), a maximum sedimentation depth of $2 \mathrm{~m}$ can be attributed to the lagoon bottom. It follows that among substages 7.3 and 5.5 there was a substantial stability, with an uplift of only $6 \mathrm{~m}(+0.06 \mathrm{~mm} / \mathrm{yr}$; Fig. 7).

In the Pt8 core, the upper part of the UCl unit is dated at $190 \pm 24$ and $199 \pm 46 \mathrm{ka}$ (samples Pt8/18 and Pt8/20; Fig. 2 and Table 2), therefore we considered the layer dated at $190 \pm 24 \mathrm{ka}$ as a marker level referable to substage 7.1. In this work, a 7.1 highstand at ca. $-15 \mathrm{~m}$ has been carefully considered, as this is an intermediate value among those reported in Schellmann and Radtke (2004), Bintanja et al. (2005) and Waelbroeck et al. (2002). The marker level of substage 7.1 accumulated in a continental environment and currently it is at $-68 \mathrm{~m}$; almost certainly it accumulated above $-10 \mathrm{~m}$ : as a precaution, this sedimentation height has been assigned to it. It follows that between substages 7.1 and 5.5 there was a subsidence of at least $30 \mathrm{~m}$, at a rate greater than $-0.4 \mathrm{~mm} / \mathrm{yr}$ (Fig. 7).

Concerning the Amendola subsynthem, even in the presence of good biological markers, such as infralittoral fauna (Pt8) and lagoonal fauna (MM4), there are no reliable datings, so their position during MIS 11 is unclear.

A second set of remarks concerns the Coppa Nevigata and Amendola highland areas. Neither has traces of MIS 5 and 7, nor have they undergone a tectonic uplift. For the Coppa Nevigata area. the marker used is the intertidal stromatolithic level of the NVI unit, whose present height is $+7 \mathrm{~m}$. Its age is $409 \pm 62 \mathrm{ka}$, therefore referable to the MIS 11 highstand. During this stage the sea level was higher than the present (Shackleton, 1987), but not all the authors agree about the maximum sea level reached in this interstadial: $+20 \mathrm{~m}$ (Howard, 1997; Hearty et al., 1999) or between +18 and + $20 \mathrm{~m}$ (Hearty and Kaufman, 2000). According to Schellmann and 

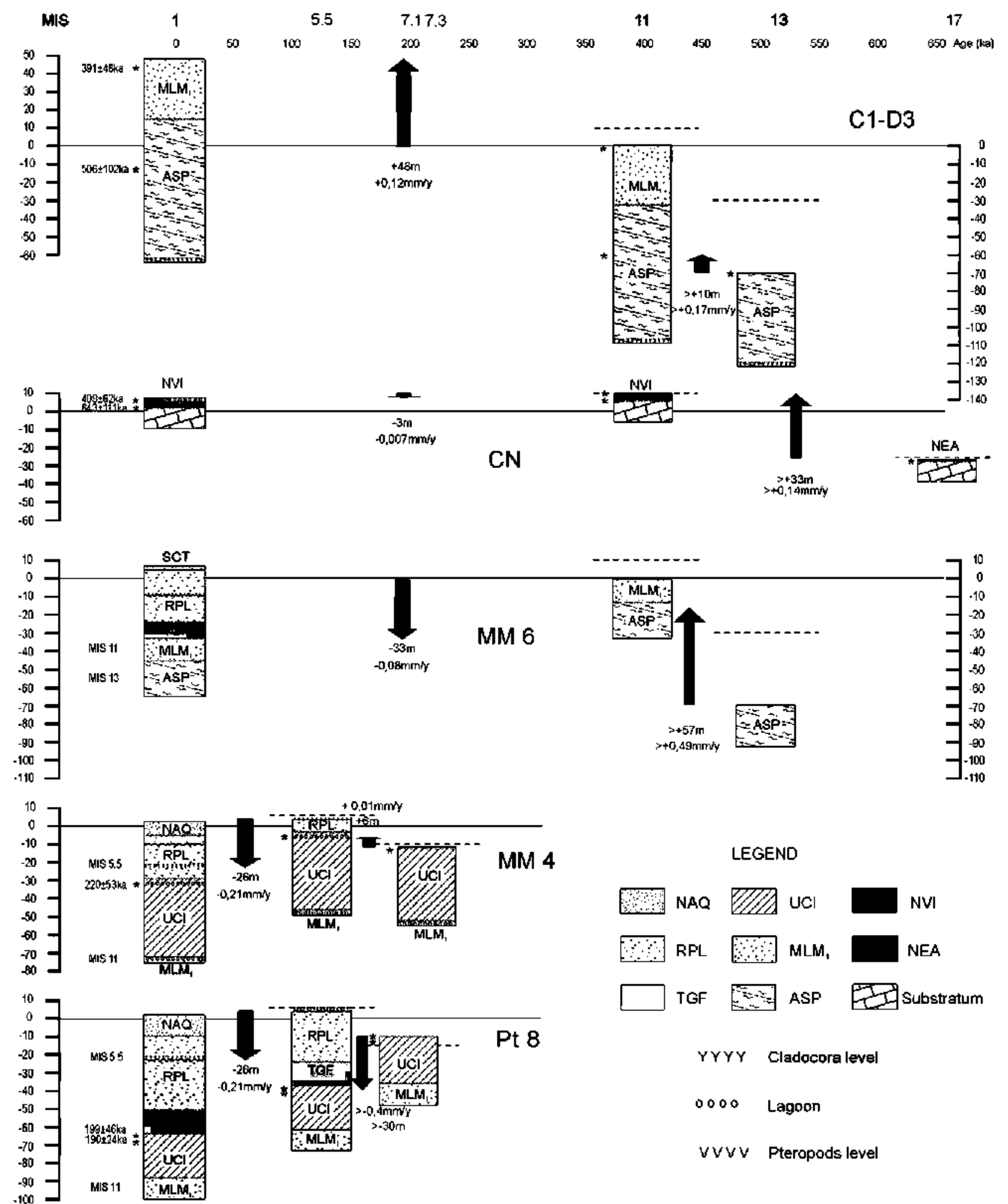

Fig. 7. Vertical movements and their rates recorded between some MIS for the following areas or localities: Amendola highland, Coppa Nevigata (CN), and boreholes MM6, MM4, and Pt 8 . The vectors indicate the direction and intensity of the movements; the continuous lines indicate the present sea level; the dashed lines indicate the past sea levels.

Radtke (2004), if the assumption of an MIS 5 highstand at $+6 \mathrm{~m}$ is accepted, a reconstructed sea level at $+18 \mathrm{~m}$ would result for the Fourth past Interglacial; instead, if the assumption of an MIS 5 highstand at $+2 \mathrm{~m}$ is accepted, a reconstructed sea level at $+5 \mathrm{~m}$ would result for the MIS 11 highstand. The latter is more or less the value considered by Waelbroeck et al. (2002). In this work a MIS 11 highstand at $+10 \mathrm{~m}$ has been considered (Schellmann and Radtke,
2004). It follows that, from MIS 11 to the present day, the Coppa Nevigata area suffered a subsidence of $3 \mathrm{~m}$, at a rough rate of $-0.007 \mathrm{~mm} / \mathrm{yr}$ (Fig. 7).

More or less at the same time, the Amendola highland underwent an uplift of more or less $48 \mathrm{~m}$, at a rate of roughly $+0.12 \mathrm{~mm} / \mathrm{yr}$ (Fig. 7). In this case, the marker used is a level with a fine well-sorted sand biocoenosis, to which a sedimentation depth of about $10 \mathrm{~m}$ has 
prudently been attributed. At present, in the Adriatic Sea, this same association does not exceed $12 \mathrm{~m}$ in depth (Morello et al., 2005), while in protected areas such as the Manfredonia gulf, it reaches the maximum growth at a lower depth. The age attributed to this level, currently sited at $+48 \mathrm{~m}$, is $391 \pm 48 \mathrm{ka}$, which corresponds to the MIS 11 highstand.

Going back in time, it is possible to hypothesise that also between MIS 13 and MIS 11 the Amendola highland suffered a tectonic uplift greater than $10 \mathrm{~m}$, at a rate greater than roughly $+0.08 \mathrm{~mm} / \mathrm{yr}$ (Fig. 7 ). In this case, the marker used is a level of the ASP unit with the coastal terrigenous mud biocoenosis, to which a sedimentation depth of about $40 \mathrm{~m}$ has been attributed. At the moment, in the Adriatic Sea, this same biocoenosis is below $50 \mathrm{~m}$ in depth (Damiani et al., 1988), but in the Manfredonia Gulf it is also at lower depths. This is due to the slow drifting, towards the sea, of the terrigenous sediments discharged by the Tavoliere rivers, because of the Gargano promontory, which acts as a barrier to the currents coming from the northern quadrants (Caldara et al., 1998). The age of this level, found in the D3 borehole at $-12 \mathrm{~m}$, is $506 \pm 102 \mathrm{ka}$. This age indicates MIS 13 , whose sea level was at least $30 \mathrm{~m}$ lower than the present (Bintanja et al., 2005).

The same situation, but with greater uncertainty, due to the lack of reliable dating for the argille subappennine unit, comes from the MM6 borehole; in this area, an uplift of about $57 \mathrm{~m}$ occurs, at a rate greater than $+0.49 \mathrm{~mm} / \mathrm{yr}$ (Fig. 5)

For the Coppa Nevigata area, it has been possible to estimate, between MIS 17 and MIS11, an uplift greater than $33 \mathrm{~m}$, at a rate exceeding $+0.14 \mathrm{~mm} / \mathrm{yr}$ (Fig. 7). The marker used is the basal fauna of the NEA unit, to which a sedimentation depth of $2 \mathrm{~m}$ has been attributed.

As the attributed temporal range for the NEA unit is MIS 17-16, it can be hypothesised, thanks to the vertical movement calculation, that the marker level of this unit accumulated during the MIS 17 highstand when the sea level was at ca. - $25 \mathrm{~m}$ (Bintanja et al., 2005).

\section{Conclusions}

The geologic study of the coastal alluvial plains has always been difficult for reasons including the very low scarps between the terraced units, the low diversification of the sediments, and the outcrop scarcity. The Apulian Tavoliere plain is no exception: here an intense calcification is added, often obliterating the few outcrops.

We have applied a method, exportable to other similar cases, using a great number of cores and the AAR dating method applied to ostracod shells. This method allows us to date marine, continental and lagoonal sediments, thanks to the capability of ostracods to colonise all environments, as long as there is water. The datings are not exhaustive if used alone, and so are considered with other data, such as the lithofacies, the faunal content, the sedimentary environment. and the general geologic context. All of these elements have allowed us to define, for all of the different units, a temporal range, and to correlate them with sea level cycles. This methodology has allowed us to recognise a different geological setting from that reported in the literature. In fact, in the coastal area of the Apulian Tavoliere plain. nine marine and continental sedimentary units, some of which do not crop out, have been recognised.

The most interesting results of this work can be summarised as follows:

I) The first numerical dates have been obtained, in the Apulian Tavoliere area, for the argille subappennine unit and some marine and continental terraced units. From these it appears that the recognised units were deposited from the middle Pleistocene (MIS 17) to the Holocene.

II) The utility and reliability of ostracods has been tested for dating terraced deposits, very often characterised by the absence of other species suitable for dating.
III) Uplift and subsidence areas have been recognised and the vertical movements have been evaluated.

IV) For the first time in the Apulian Tavoliere plain, MIS 5 deposits have been recognised; the finding of a $C$. caespitosa layer referable to MIS 5.5, lacking in warm fauna, is particularly important. This is the first Tyrrhenian level with $C$ caespitosa found along the Adriatic coast; the presence of this coral in clayey sediments, a very uncommon thing, strengthens the hypothesis that the major fossil reefs grew in coastal waters characterised by alluvial inputs of fine sediments, higher turbidity and higher temperatures than today. In addition, on the basis of the current evidence, some consideration about the fauna of the MIS 5.5 layer allows us to hypothesise that the Adriatic Sea underwent a more moderate warming than the Ionian and Tyrrhenian seas. Instead, the finding, in the NVI unit. of a tropical lagoonal deposit with stromatolites referred to MIS 11, proves that the warming of this stage was undoubtedly greater than that of MIS 5.5 .

V) We have recognised two marine phases during MIS 5: the first is referable to MIS 5.5-5.3, and the second to MIS 5.1. MIS 5.2 is marked by land emersion. whereas no evidence of land emersion between MIS 5.5 and 5.3 has been found.

vi) The finding of the buried C. caespitosa layer also allowed us to fill a gap in the data regarding the recent tectonic movements along the Adriatic coast (Ferranti et al., 2006): in fact, it proves that there has been a recent subsidence since MIS 5.5 in the coastal area of the Apulian Tavoliere plain.

The results obtained here are encouraging and they encourage us to extend this method to all areas where there are continental and marine terraced sediments that are difficult to date.

\section{Acknowledgements}

We thank the staff of the Italian Geological Survey (ISPRA) for their suggestions and technical support. We are grateful to Grace Carone and Elsevier Language Editing Service for the English revision. This work has been financed by Regione Puglia and the Italian CARG project.

\section{References}

Amorosi, A., Colalongo, M.L, Pasini, G., Preti, D., 1999a. Sedimentary response to late quaternary sea-level changes in the Romagna coastal plain (northern Italy). Sedimentology 46, 99-121.

Amorosi, A. Colalonto M.L. Fusco, F. Pasini, Fiorini F, 1999b. Glacio-eustatic control of continental-shallow marine ciclicity from Late Ouaternary deposits of the southeastem Po Plain, Northern Italy. Quaternary Research 52, 1-13.

Amorosi, A., Colalongo, M.L., Fiolini, F., Fusco, F., Pasini, Vaiani, S.C., Sarti, G., 2004 Palaeogeographic and palaeoclimatic evolution of the Po Plain from 150 ky core records. Global and Planetary Change 40, 55-78.

Antonioli, F., Girotti, O., Improta, S., Nisi, M.F., Puglisi, C., Verrubbi, V., 1999. Nuovi dati sulla trasgressione marina olocenica e la subsidenza della pianura versiliese attravelso un sondaggio di $90 \mathrm{~m}$. Atti Conf. "Le pianure, conoscenza e salvaguardia", Regione Emilia-Romagna, 8-11 Novembre 1999, Ferrara, pp. 214-218.

Azzaroli, A., Pemo, V., Radina, B., 1968. Note illustrative della Carta Geologica d'Italia, $F^{\circ}$ 188 "Gravina di Puglia". Servizio Geologico d'Italia, Roma.

Balescu, S., Dumas, B., Guérémy, P., Lamothe, M., Lhênaff, R, Raffy, J., 1997 Thermoluminescence dating tests of Pleistocene from uplifted shorelines along the southwest codstline of the Calabrian Peninsula (southern Italy). Palaeogeography, Palaeoclimatology, Palaeoecology 130, 25-41.

Balra, D., Cinque, A., Gedwelt, M., Hurtgen, C., 1991. L'ospite caldo sylvestra seminis (Crustacea, Ostracoda; Bonaduce, Masoli \& Pugliese, 1976): un possiblie marke dell'ultimo interglaciale dell'area mediterranea. Il Quaternario 4 (2), 327-332.

Belluomini, G. Caldara, M. Casini, C. Celasoli, M., Manfra, L. Mastronuzzi, G. Palmentola, G., Sansó, P., Tuccimei, P., Vesica, P.L, 2002. The age of Late Pleistocene shorelines and tectonic activity of Taranto area, Southern Italy. Quaternary Science Reviews 21, 525-547.

Bintanja, R., van de Wal, R.S.W., Oerlemans, J., 2005. Modelled atmospheric temperatures and global sea levels over the past million years. Nature Letters 437 (1), 125-128.

Boenzi, F., Palmentola, G., Pieri, P., Valduga, A, 1971a. Note illustrative della Carta geologica d'Italia alla scala 1:100.000. Fogli 165 e 176 Trinitapoli e Barletta. Servizio Geologico d'Italia, Roma. 
Boenzi, F., Caldara, M., Pennetta, L., 1991. Osservazioni stratigrafiche e geomorfologiche nel tratto meridionale della piana costiera del Tavoliere di Puglia. Geografia Fisica e Dinamica Quaternalia 14 (1), 23-31.

Boni, A, Casnedi, R., Centenaro, E., Colantoni, P., Cremonini, G., Elmi, C., Monesi, A., Selli, R., Valletta, M., 1969. Note illustrative della Carta Geologica d'Italia, alla scala 1:100.000, Foglio 155 "S.Severo". Servizio Geologico d'Italia, Roma

Brancaccio, L., Capaldi, G., Cinque, A. Pece, R., Sgrosso, I. 1978. ${ }^{230} \mathrm{Th}-{ }^{238} \mathrm{U}$ dating of corals from a Tyrrhenian beach in Sorrentine Seninsula (Southern Italy). Quaternaria 20, 175-183.

Caldara, M. 1986. La sezione tirreniana di ponte del Re (Castellaneta Marina, Taranto): analisi paleoecologica. Atti della Società Tostana di Scienze Naturali XCIII, pp. 129-163.

Caldara, M., Pennetta, L., 1991. Pleistocenic buried abrasion platforms in southeastern Tavoliere (Apulia, South Italy). II Quaternario 4 (2), 303-309.

Caldara, M., Pennetta, L, 1993. Nuovi dati per la conoscenza geologica e morfologica del Tavoliere di Puglia. Bonifica 8 (3), 25-42.

Caldara, M., Simone, O., 2005. Coastal changes in the eastern Tavoliere Plain (Apulia, Italy) during the Late Holocene: natural or anthropic? Quaternary Science Reviews $24,2137-2145$

Caldara, M. Centenaro, E., Mastronuzzi, G., Sanso', P., Sergio, A, 1998. Features and present evolution of apulian coast (Southem Italy). Joumal of Coastal Research, SI $26,55-64$.

Caldara, M., Pennetta, L., Simone, 0., 2002. Holocene evolution of the Salpi Lagoon (Puglia, Italy). Journal of Coastal Research SI 36, 124-133.

Caldara, M., Capolongo, D., Del Gaudio, V., De Santis, V., Pennetta, L., Maiorano, P., Simone, 0. Vitale, $G$., in print Note illustrative della Carta Geologica d'Italia alla scala 1:50.000 Foglio, 422 "Cerignola". ISPRA, Roma.

Cantelli, C., 1960. Sul Quatemario di Gravina in Puglia. Giornale di Geologia 28 (ser.n 2), 211-226.

Caputo, R. 2007. Sea-level curves: perplexities of an end-user in molphotectonic applications. Global and Planetary Change 57, 417-423.

Carnicelli, S., Ferrari, GA., Magaldi, D., Bilwiller, G., Di Nocera, S., Palmentola, G., Pennetta, L., Zamparelli, V., 1989. Les accumulations carbonatées de type "calcrete" dans les sols et formations superficielles d'Italie meridionale. Mediterranée 68 (2-3), 51-59.

Chappell, J., Shackleton, N.J., 1986. Oxygen isotopes and sea-level. Nature 324, 136-140.

Ciaranfi, N., 1983. Osservazioni geologiche e molfologiche sull'entroterra del Golfo di Manfredonia ( $F^{\circ} 164$ I NO. I SO. IV NE. IV SE). Studi sul Neolitico del Tavoliere di Puglia. British Archaeological Reports, Intemational series 160, 203-222.

Ciaranfi, N., Pieri, P., Ricchetti, G., 1992. Note alla calta geologica delle Murge e del Salento Puglia centromeridionale. Memorie Società Geologica Italiana 41 (1988), $449-460$.

Ciaranfi, N., Loiacono, F., Moretti, M., in print. Note illustrative della Carta Geologica d'Italia alla scala 1: 50.000 , Foglio 408 "Foggia". ISPRA, Roma.

Clarke, S.J., Murray-Wallace, C.V., 2006. Mathematical expressions used in amino acid racemisation geochronology - a review, Quaternary Geoclironology 1, 261-278.

Coltorti, M., Farabollini, P., 2008. Late Pleistocene and Holocene fluvial-coastal evolution of an uplifting area: the Tronto River (Central Eastern Italy). Quaternary International 189, 39-55.

Dai Pra, G. Hearty. P.J., 1988. I livelli marini pleistocenici del Golfo di Taranto. Sintesi geocronostratigrafica e tettonica. Memorie della Società Geologica Italiama 41. $637-644$.

Dai Pra, G., Miyauchi, T., Anselmi, B., Galletti, M., Paganin, G., 1993. Età dei depositi a Strombus bubonius di Vibo Valentia Marina (Italia Meridionale). Il Quaternario 6 (1), 139-144.

Damiani, V., Bianchi, C.N., Ferretti, O., Bedulli, D., Morli, C., Viel, M., Zurlini, G., 1988. Risultati di una ricerca ecologica sul sistema marino costiero pugliese. Thalassia salentina $18,153-169$

Di Geronimo, I., 1984. Stabilité des peuplements benthique et stabilité des bassins sédimentaires. Geobios Mémoire spécial 8, 145-150.

Doglioni, C., 1991. A proposal for kinematic modelling for W-dipping subductions possible applications to the Tyrrhenian-Apennines system. Terra Nova 3,423-434.

Doglioni, C. Mongelli, F., Pieri, P., 1994. The Puglia uplift (SE Italy): an anomaly in the foreland of the Apenninic subduction due to buckling of a thick continental lithosphere. Tectonics $13(5), 1309-1321$.

Doglioni, C., Tropeano, M., Mongelli, F., Pieri, P. 1996. Middle-late Pleistocene uplift of Puglia: an anomaly in the Apenninic foreland. Memorie Società Geologica Italiana 51. 101-117.

Esposito, C., Filocamo, F., Marciano, R., Romano, P., Santangelo, N., Scarciglia, F., Tuccimei, P., 2003. Late Quatemary shorelines in southern Cilento (Mt. Bulgheria): morphostratigraplyy and clmonology. II Ouaternario 16 (1), 3-14

Ferranti, L., Antonioli, F, Mauz, B., Amorosi, A., Dai Pra, G., Mastronuzzi, G. Monaco, $C$, Orru, P., Pappalardo, M., Radtke, U., Renda, P., Romano, P., Sansó, P., Verrubbi, V. 2006. Markers of the last interglacial sea-level high stand along the coast of Italy: tectonic implications. Quaternary International 145-146, 30-54.

Fleming, K., Johnston, P., Zwartz, D., Yokoyama, Y., Lambeck, K., Chappell, J., 1998. Refining the eustatic sea-level curve since the Last Glacial Maximum using far- and intermediate-field sites. Earth and Planetary Science Letters 163, 327-342.

Gliozzi, E., 1987. I terrazzi del Pleistocene superiore della penisola di Crotone (Calabria). Geologica Romana 26, 17-79.

Hearty, P.J., 1986. An inventory of last interglacial (sensu lato) age deposits from the Mediterramean Basin: a study of isoleucine epimerization and U-series dating. Zeitschrift fur Geomorphologie, Supplementum 62, 51-69.

Hearty, P.J., 1987. New data on the Pleistocene of Mallorca. Quatemary Science Reviews $6,245-257$.

Hearty, P.J., Kaufman, D.S., 2000. Whole-rock aminostratigraphy and Quaternary sealevel history of the Bahamas. Quatemaly Researcl 54, 163-173.
Hearty, P. J, Kinder, P., Cheng, H. Edwards, R.L., 1999. A + 20 m middle Pleistocene sealevel highstand (Bermuda and the Bahamas) due to partial collapse of Antarctic ice. Geology 27 (4), 375-378.

Howard, W.R., 1997. A warm future in the past. Nature 388, 418-419.

Imbrie, J., Hays, J.D., Martinson, D.G. McIntyre, A., Mix, A.C. Morley, J. J. Pisias, N.G., Prell, W.L., Shackleton, N.J., 1984. The orbital theory of Pleistocene climate: support from a revised chronology of the marine ${ }^{18} 0$ record. In: Berger, A., Imbrie, J., Hays, J. Kukla, G., Saltzman, B. (Eds.), Milankovitch and Climate. Reidel Publishing Company, Dordrecht, pp. 269-305.

Jacobacci. A., Malatesta, A. Martelli, G., Stampanoni, G., 1967. Note Illustrative della Carta Geologica d"Italia alla scala 1:100.000, Foglio 163 "Lucera". Servizio Geologico d'Italia, Roma.

Kaufmaln, DS., 2000. Amino acid racemization in ostracodes. In: Goodfriend, G.A. Collins, M.J., Fogel, M.L., Macko, S.A., Wehmiller, J.F. (Eds.), Perspectives in Amino Acids and Protein Geochemistry, Oxford Univ, Press, New York, pp. 145-160.

Kaufman, D.S., Forman, S.L., Bright, J., 2001. Age of the Cutler Dam (late Pleistocene) alloformation, Bonneville Basin. Quaternary Research 56, 322-334.

Kruzic, P., Zuljevic, A., Nicolic, V., 2008. Spawning of the colonial Cladocora caespitosa (Anthozoa, Scleractinia) in the Southern Adriatic Sea. Coral Reefs 27, 337-341.

Lambeck, K., Antonioli, F., Purcella, A. Silenzi, S., 2004a. Sea-level change along the Italian coast for the past 10,000 yr. Quaternary Science Reviews 23, 1567-1598.

Lambeck, K., Antonioli, F., Purcell, T., Stirling, C., 2004b. MIS 5.5 sea level in the Mediterranean and inferences on the global ice volumes during late MIS 6 and MIS 5.5. Final Proc. 32nd International Geological Congress, Florence, Italy.

Leigh, DS. Srivastava, P., Brook, GA. 2004. Late Pleistocene braided rivers ofthe Atlantic Codstal Plain, USA. Quaternary Science Reviews 23, 65-84.

Malatesta, A., Perno, U., Stampanoni G., 1967. Note illustrative della Carta Geologica d'Italia alla scala 1:100.000, Foglio 175 "Cerignola". Servizio Geologico d'Italia Roma.

Malinverno, A, Ryan, W.B.F., 1986. Extension in the Thrrhenian sea and shortening in the Appennines as result of arc migration driven by sinking of the litosphere. Tectonics 5, 227-245.

Marsico, A., Selleri, G. Mastronuzzi, G., Sansỏ, P., Walsh, N., 2003. Cryptokarst: a casestudy of the Ouatermary landforms of southern Apulia (Southern Italy). Acta Carsologica $32(2), 147-159$

McCoy. W.D., 1987. The precision of amino acid geochronology and paleothermometry. Quaternary Science Reviews 6. 43-54

McCoy, W.D. 1988. Amino acid racemization in fossil non-marine ostracod shells: potential tool for the study of Quaternary stratigraphy. chronology and palaeotemperature. In: De Deckker, P., Colin, J.P., Peypouquet, J.P. (Eds.), Ostracoda in the Earth Sciences. Amsterdam \& New York, Eselvier, pp. 201-218.

Merla, G., Ercoli, A., Torre D., 1969. Note illustrative della Carta Geologica d'Italia alla scala 1:100.000, Foglio 164 "Foggia". Servizio Geologico d"Italia, Ercolano (NA).

Migliorini, C., 1937. Cenno sullo studio e sulla prospezione petrolifera di una zona dell'Italia meridionale. II Congresso Mondiale del Petrolio di Parigi (10 pp)

Miller, G.H. Paskoff, R, 1986. Amino-acid geochronology of Pleisocene littoral deposits in Tunisia. Zeitschrift fur Geomorphologie. Supplementum 62, 197-207.

Morello, E.B., Froglia, C. Atkinson, R.J.A., Moore, P.G. 2005. Hydraulic dredge discards of the clam (Chamelea gallina) fishery in the western Adriatic Sea, Italy. Fisheries Research 76, 430-444.

Nisi, M.F., Antonioli, F., Dai Pra, G., Leoni, G., Silenzi, S., 2003. Coastal deformation between the Versilia and the Garigliano plains (Italy) since the last interglacial stage. Journal of Ouaternary Stience $18(8), 709-721$.

O'Leary, M.J., Hearty, P.J., McCulloch, M.T., 2008. U-series evidente for widespread reef development in Shark Bay during the last interglacial. Palaeogeography. Palaeoclimatology, Palaeoecology 259, 424-435.

Ortiz. J.E. Torres, T. Llamas, FJ 2002. Cross-calibration of the racemization rates of leucine andphenylalanine and epimerization rates of isoleucinebetween ostracodes and gastropods over the Pleistocene in southern Spain. Organic Geochemistry 33, 691-699.

Ortiz, J.E., Torres, T., Juliă, R., Delgado, A, Llamas, F.J., Soler, V., Delgado, J., 2004 Numerical dating algorithms of amino acid racemization ratios from continental ostracodes. Application to Guadix-Baza basin (southern Spain). Quaternary Science Reviews 23 (5-6), 717-730.

Oviatt, C.G., Thompson, R.S, Kaufinan, DS., Bright, J., Forester, R.M, 1999. Reinterpretation of the Burmester Core, Bonneville Basin, Utah. Ouatemary Research 52, 180-184.

Patacca, E., Standone, P., 1989. Post-Tortonian mountain building in the Apennines. The role of the passive sinking of a relict lithospheric slab. In: Boriani, A., Bonafede, M. Piccardo, G.B., Vai, G.B. (Eds.), The Lithosphere in Italy. : Advances in Earth Science Research. Accademia dei Lincei, Roma, pp. 157-176.

Patacca, E.. Scandone, P. 2001. Late thrust propagation and sedimentaly response in the thrust belt-foredeep system of the Southern Apennines (PliocenePleistocene). In: Vai, G.B., Martini, I.P. (Eds.). Anathomy of an Orogen: The Apennines and Adjacent Mediterranean Basins. Kluwer Academic Publ Dordrecht, pp. 404-440.

Peiramo, A. Morri, C., Mastronuzzi, G., Bianchi, C.N., 1998. The colal Clodocora caespitoso (Anthozoa, Scleractinia) as a bioherm builder in the Mediterranean Sea. Memorie Descrittive Carta Geologica d'Italia LII 59-74.

Peirano, A., Morri, C., Bianchi, C.N., Aguirre, J., Antonioli, F., Calzetta, G., Carobene, $L$ Mastronuzzi, $G$, Orru, $\mathrm{P}, 1994$. The Mediterranean coral Cloniocora caespitosa: a proxy for past climate fluctuations? Global and Planetaly Cliange $40,195-200$.

Peirano, A, Kruzic, P., Mastronuzzi, G., 2009. Growth of Mediterranean reef of Cladocoro caespitose ( $\mathrm{L}$ ) in the Late Quaternary and climate inferences. Facies 55, 325-333.

Pérès, J.M. 1967. The Mediterranean benthos. Oceanography Marine Biology Annual Review 5, 449-533. 
Picard, J. 1965. Recherches qualitatives sur les Biocoenoses marines des substrts meubles dragables de la région marseillaise. Recueil des Travaux de la Station Marine d'Endoume 36 (52), 1-102 (Marseille).

Poole, A. Shimmield, G.B., Robertson, A.H.F., 1990. Late Quaternary uplift of the Troodos ophiolite, Cyprus. Uranium series dating of Pleistocene colal. Geology 18, 894-897.

Ricchetti, G., 1967. Lineamenti geologici e morfologici della media valle del fiume Basento. Bollettino Società Geologica Italialna 86, 607-622.

Ricchetti, G., 1981. Contributo alla conoscenza della Fossa bradanica e delle Murge Bollettino Società Geologica Italiana $99(1980), 421-430$.

Ricchetti, G., Ciaranfi, N., Luperto Simi, E., Mongelli, F., Fieri, P., 1992. Geodinamica ed evoluzione sedimentaria e tettonica dell'avampaese apulo. Memorie Società Geologica Italiana 41 (1988), 57-82.

Romano, P., Santo, A., Voltaggio, M., 1994. L'evoluzione geomorfologica della pianura del fiume Voltumo (Campania) durante il tardo Quatemario (Pleistocene mediosuperiore - Holocene), Il Ouatemario 7 (1), 41-56.

Royden, L., Patacca, E., Scandone, P., 1987. Segmentation and configuration of subducted lithosphere in Italy: an important control on thrust belt and foredeepbasin evolution. Geology 15, 714-717.

Salvador, A, 1987. Unconformity-bounded stratigraphic unit. Geological Society of America Bulletin 98, 232-237.

Schellmamn, G., Radtke, U., 2004. A revised morpho- and chronostratigraphy of the Late and Middle Pleistocene coral reef terraces on Southem Barbados (West Indies) Eartl-Science Reviews 64, 157-187.

Schroeder, R.A. Bada, J.L, 1976. A review of the geochemical applications of the aminoacid racemization reaction. Earth Science Reviews 12, 347-391.
Schumm, S. Kahn, H. 1972. Experimental study of channel patterns. Bulletin of the Geological Society of America 83, 1755-1770.

Shackleton, N.J., 1987. Oxygen isotopes, ice volumes and sea-level. Quaternaly Science Reviews 6, 183-190.

Sivan, D., Gvirtzman, G., Sass, E., 1999. Quaternaly stratigraplyy and paleogeograplyy of the Galilee coastal plain, Israel. Quaternary Research 51, 280-294.

Torres, T., Llamas, J., Canoira, L., Garcla-Alonso, P., Garcla-Cortes, A., Mansilla, H., 1997. Amino acid clronology of the Lower Pleistocene deposits of Venta Micena (Orce. Granada, Andalusia, Spain). Organic Geochemistry 26, 85-97.

Torres, T., Llamas, J., Canoira, L. Coello, F.J., Garcia Alonso, P., Ortiz, J.E., 2000. Aminostratigraphy of two Pleistocene marine sequences from the Mediterranean coast of Spain: Cabo de Huertas (Alicante) and Garnucha (Almeria). In: Goodfriend G.A., Matthew, J.C., Marilyn, L.F., Stephen, A.M., John. F.W. (Eds.), Pelspectives in Amino Acid and Protein Geochemistry. Oxford University press, Oxford, pp. 263-278.

Ulzega, A Hearty, P.J. 1986. Geomolphology, stratigraply and geoclnonology of Late Quaternaly marine deposits in Sardinia. Zeitschrift fur Geomorphologie. Supplementum 62, 119-129.

Waelbroeck, C., Labeyrie, L., Michel, E., Duplessy, J.C., McManus, J.F., Lambeck, K, Balbon, E., Labracherie, M., 2002. Sea-level and deep water temperature changes derived from benthic foraminifera isotopic records. Quaternary Science Reviews 21, 295-305.

Zazo, C., 1999. Interglacial sea levels. Quatemary Intemational 55, 101-113.

Zecchin, M., Nalin, R., Roda, C., 2004. Raised Pleistocene marine ternaces of the Crotone peninsula (Calabria, southern Italy): facies analysis and organization of their deposits. Sediedmentary Geology 172, 165-185. 